\title{
The OMP-lacZ Transgene Mimics the Unusual Expression Pattern of OR-Z6, a New Odorant Receptor Gene on Mouse Chromosome 6: Implication for Locus-Dependent Gene Expression
}

\author{
Martina Pyrski, ${ }^{1}$ Zheng Xu, ${ }^{1}$ Eric Walters, ${ }^{2}$ Debra J. Gilbert, ${ }^{3}$ Nancy A. Jenkins, ${ }^{3}$ Neal G. Copeland, ${ }^{3}$ and \\ Frank L. Margolis ${ }^{1}$ \\ 1Department of Anatomy and Neurobiology, School of Medicine, University of Maryland at Baltimore, Baltimore, Maryland \\ 21201, ${ }^{2}$ Department of Biochemistry and Molecular Biology, Howard University Medical College, Washington, DC 20059, \\ and ${ }^{3}$ Mouse Cancer Genetics Program, National Cancer Institute-Frederick, Frederick, Maryland 21702
}

Reporter gene expression in the olfactory epithelium of H-lacZ6 transgenic mice mimics the cell-selective expression pattern known for some odorant receptor genes. The transgene construct in these mice consists of the lac $Z$ coding region, driven by the proximal olfactory marker protein (OMP) gene promoter, and shows expression in a zonally confined subpopulation of olfactory neurons. To address mechanisms underlying the odorant receptor-like expression pattern of the lacZ construct, we analyzed the transgene-flanking region and identified OR$Z 6$, the first cloned odorant receptor gene that maps to mouse chromosome 6 . OR-Z6 bears the highest sequence similarity $(85 \%)$ to a human odorant receptor gene at the syntenic location on human chromosome 7 . We analyzed the expression pattern of OR-Z6 in olfactory tissues of H-lacZ6 mice and show that it bears strong similarities to that mapped for $\beta$-galactosidase. Expression of both genes in olfactory neurons is primarily restricted to the same medial subregion of the olfactory epithelium. Axons from both neuronal subpopulations project to the same ventromedial aspect of the anterior olfactory bulbs. Furthermore, colocalization analyses in $\mathrm{H}-\mathrm{lacZ6}$ mice demonstrate that $O R-Z 6$-reactive glomeruli receive axonal input from lacZ-positive neurons as well. These results suggest that the expression of both genes is coordinated and that transgene expression in $\mathrm{H}-\mathrm{lacZ6}$ mice is regulated by locusdependent mechanisms.

Key words: transgene; receptors; OR-Z6; olfactory neurons; olfactory epithelium; olfactory bulb; expression patterns; in situ hybridization; locus dependence; OMP promoter
The vertebrate olfactory system is remarkable in its ability to detect and discriminate among thousands of different odorants. Tremendous progress has been made in understanding odorant detection that is mediated by odorant receptor (OR) proteins located in the ciliary membrane of the olfactory receptor neurons (ORNs), a bipolar neuron population that resides in the olfactory epithelium (OE) of the vertebrate nose. Vertebrate ORNs are unusual in that they can be replaced throughout life via progenitor cell proliferation and differentiation (Graziadei and Graziadei, 1979). Each ORN seems to express a single OR gene from a family that is estimated to number as many as 1000 different genes in rodents (Buck and Axel, 1991). ORNs expressing a given OR gene exhibit a mosaic-like distribution within one of four suggested zones of the neuroepithelium (Ressler et al., 1993; Strotmann et al., 1994a,b; Vassar et al., 1994), and their axons project onto defined glomeruli in the olfactory bulb (OB) (Ressler et al., 1994; Vassar et al., 1994; Mombaerts et al., 1996). The mechanisms underlying these expression patterns are still elusive but likely depend on a complex interplay including allelic exclusion,

Received Dec. 20, 2000; revised April 3, 2001; accepted April 5, 2001.

This research was supported in part by National Institutes of Health Grants DCD03112 (F.L.M.) and U54NS39407 (E.W.) and by the National Cancer Institute, Department of Health and Human Services (N.G.C., N.A.J., and D.J.G.). We thank Drs. A. Puche and O. Buiakova for helpful discussions and S. Moussavi and Deborah B. Householder for excellent technical assistance.

Correspondence should be addressed to Dr. F. L. Margolis, University of Maryland at Baltimore, School of Medicine, Department of Anatomy and Neurobiology, 685 West Baltimore Street, Health Science Facility 273, Baltimore, MD 21201. E-mail: fmargoli@umaryland.edu.

Copyright (C) 2001 Society for Neuroscience 0270-6474/01/214637-12\$15.00/0 locus control elements, and zonally active transcription factors during early development (Ressler et al., 1993; Chess et al., 1994; Sullivan et al., 1996; Ebrahimi et al., 2000). Chromosomal localization studies showed that OR genes are present on several chromosomes where they often exist as clusters (Ben-Arie et al., 1994; Asai et al., 1996; Sullivan et al., 1996; Trask et al., 1998). Recent studies revealed that highly homologous genes from a cluster exhibit expression in identical zones (Strotmann et al., 1999; Tsuboi et al., 1999; Serizawa et al., 2000). However, the relation between locus and zonal confinement is probably more complex because many receptors expressed in the same zone reside at different loci and vice versa (Sullivan et al., 1996).

To address the molecular and cellular bases of OR gene expression, we analyzed the transgenic mouse line H-lacZ6 (Walters et al., 1996a,b) in which transgene expression mimics the expression pattern demonstrated for some OR genes (Ressler et al., 1993; Vassar et al., 1993; Strotmann et al., 1994a,b). Transgene expression in H-lacZ6 mice is restricted to a subpopulation of ORNs primarily located on the tips of endoturbinate-II and -III and ectoturbinate-3 (Treloar et al., 1996; Walters et al., 1996a), the axons of which terminate in closely associated glomeruli in the ventromedial aspects of the anterior OBs (Treloar et al., 1996; Cummings et al., 2000). This pattern prompted us to hypothesize that the lac $Z$ transgene has inserted under the control of an OR gene locus, and we analyzed the region flanking the insertion site for the presence of OR genes. Our hypothesis was supported by the subsequent identification of the new odorant receptor gene $O R-Z 6$ that not only resides in proximity to the transgene locus on mouse chromosome 6 but also exhibits an expression pattern 
similar to that of the transgene in $\mathrm{H}$-lacZ6 mice. Our results strongly suggest that the expression of both genes in H-lacZ6 mice is subject to similar locus-dependent regulatory mechanisms.

\section{MATERIALS AND METHODS}

$H$-lacZ6 mouse line. The generation of the transgenic mouse line H-lacZ6 was reported previously (Walters et al., 1996a). In brief, the transgene construct used [H-olfactory marker protein $(O M P)-l a c Z]$ consists of a truncated $O M P$ promoter $(-239$ to +55 bp of the rat $O M P$ gene that carry the proximal olf-1, $\mathrm{O} / \mathrm{E} 1$ binding site) fused to the $\beta$-galactosidase coding region and the Simian virus 40 (SV40) polyadenylation signal (Kudrycki et al., 1993). Experiments were performed on homozygous mice of the transgenic $\mathrm{H}$-lacZ6 line. Procedures involving the use of animals were approved by the Institutional Animal Care and Use Committee of the University of Maryland School of Medicine.

Cloning of transgene-flanking sequences. A genomic library in $\lambda$ DashII (Stratagene, La Jolla, CA) was prepared from homozygous H-lacZ6 mice, and plaque lifts from $\sim 1 \times 10^{6}$ phages were screened with an $\left[\alpha^{-}{ }^{32} \mathrm{P}\right] \mathrm{dCTP}$-labeled lac $Z$ probe $\left(1.3 \times 10^{6} \mathrm{cpm} / \mathrm{ml}\right)$ according to standard procedures (final washes in $2 \times$ SSC and $0.5 \%$ SDS at $60^{\circ} \mathrm{C}$ ). Random primed labeling of a gel-purified 1891 bp EcoRV-EcoRI restriction fragment of the lacZ coding region [pMC1871 lacZ-plasmid (Amersham Pharmacia Biotech, Piscataway, NJ)] was performed using $\left[\alpha-{ }^{32} \mathrm{P}\right] \mathrm{dCTP}(3000 \mathrm{Ci} / \mathrm{mmol})$ and the Ready-To-Go DNA-labeling kit (Amersham Pharmacia Biotech). DNA from two different phages, obtained after three rounds of screening, was purified ( $\lambda$-Magic Minipreps; Promega, Madison, WI) and mapped by restriction digestion, partial sequence analysis, and Southern blot hybridization using ${ }^{32} \mathrm{P}$-labeled probes for the $O M P$ promoter (296 bp of the proximal region) and the SV40 sequence that hybridize to the $5^{\prime}$-end and $3^{\prime}$-end of the transgene construct, respectively. Probe labeling was as described. Phage $\lambda 8$ contained a nontruncated copy of the transgene construct in the correct order of $O M P-l a c Z-S V 40$ plus $12 \mathrm{~kb}$ of genomic downstream sequence and was further analyzed by restriction digestion and Southern blot hybridization using the $\alpha^{-}{ }^{32} \mathrm{P}$-labeled SV40 DNA probe. An 874 bp XbaI hybridization product was excised from the gel, purified (Qiagen, Valencia, CA), and subcloned into an $X b a$ I-linearized vector (pBluescript; Stratagene). Sequence analysis using T3 and T7 vector primers showed that the fragment contained the transition between the $3^{\prime}$-end of the transgene construct (246 bp of SV40 sequence) and downstream flanking genomic DNA (629 bp). The 629 bp flanking fragment was PCRamplified using primers EW1 and EW20; the amplicon was subjected to restriction digestion using Bam HI and XbaI enzymes (the Bam HI site had been introduced by primer EW1) and directionally subcloned into pBluescript (clone pBSKS3'-flank).

Interspecific mouse backcross mapping. Interspecific backcross progeny were generated by mating $(\mathrm{C} 57 \mathrm{BL} / 6 \mathrm{~J} \times$ Mus spretus $) \mathrm{F} 1$ females and C57BL/6J males as described (Copeland and Jenkins, 1991). A total of $205 \mathrm{~N} 2$ mice were used to map the Hlz6 locus. DNA isolation, restriction enzyme digestion, agarose gel electrophoresis, Southern blot transfer (Hybond- $\mathrm{N}^{+}$nylon membrane; Amersham Pharmacia Biotech), and hybridization were as described (Jenkins et al., 1982). The probe, the 629 bp 3'-flanking fragment of mouse genomic DNA, was labeled with $\left[\alpha-{ }^{32} \mathrm{P}\right] \mathrm{dCTP}$ using a nick translation labeling kit (Boehringer Mannheim, Indianapolis, IN); washing was done to a final stringency of $0.8 \times$ SSC-phosphate and $0.1 \%$ SDS, $65^{\circ} \mathrm{C}$. A fragment of $6.1 \mathrm{~kb}$ was detected in SphI-digested C57BL/6J DNA, and a fragment of $8.4 \mathrm{~kb}$ was detected in SphI-digested M. spretus DNA. The presence or absence of the $8.4 \mathrm{~kb}$ SphI M. spretus-specific fragment was followed in backcross mice. A description of the probes and restriction fragment length polymorphisms (RFLPs) for the loci linked to Hlz6 including Ptn, Tcrb, and Hoxa5 has been reported previously (Siracusa et al., 1991; Li et al., 1992). Recombination distances were calculated using Map Manager, version 2.6.5. Gene order was determined by minimizing the number of recombination events required to explain the allele distribution patterns.

P1 clones. Two primers generated from the 3 '-flanking fragment (clone pBSKS3'-flank) were used to screen a wild-type mouse genomic library in P1 phagemids by PCR (Genome Systems, St. Louis, MO). Primers ps2 and ps4 yielded a 160 bp amplicon. The four P1 clones obtained (P1 clones 6386-6389) were confirmed to map to the Hlz6 locus by PCR using the same primers. PCR standard conditions were $10 \mathrm{~mm}$ Tris- $\mathrm{HCl}$, pH 9, $50 \mathrm{~mm} \mathrm{KCl,} \mathrm{0.1 \%} \mathrm{Triton} \mathrm{X-100,} 0.2 \mathrm{~mm}$ each dNTP, $2 \mathrm{~mm} \mathrm{MgCl}_{2}$, $2.5 \mathrm{U}$ of Taq polymerase (Promega), and $0.2 \mu \mathrm{M}$ each primer. Cycling parameters were $5 \mathrm{~min}$ at $95^{\circ} \mathrm{C}$, followed by 35 cycles of $1 \mathrm{~min}$ at $60^{\circ} \mathrm{C}, 1.5$ min at $72^{\circ} \mathrm{C}$, and $1 \mathrm{~min}$ at $96^{\circ} \mathrm{C}$ and a final extension for $20 \mathrm{~min}$ at $72^{\circ} \mathrm{C}$.

Cloning of OR-Z6. P1 clones 6386-6389 (cre ${ }^{-}$-bacterial host strain NS3516; Genome Systems) were grown in LB medium (Life Technologies, Rockville, MD) supplemented with $20 \mu \mathrm{g} / \mathrm{ml} \mathrm{Kanamycin} \mathrm{(Sigma,}$ St. Louis, MO), and P1 DNA from $5 \mathrm{hr}$ cultures was purified according to the manufacturer's recommendations. Each $50 \mathrm{ng}$ of P1 DNA was subjected to PCR using the degenerate primers p26 and p27 each at $2 \mu \mathrm{M}$. Cycling parameters were $5 \mathrm{~min}$ at $95^{\circ} \mathrm{C}$, followed by 45 cycles of $2 \mathrm{~min}$ at $50^{\circ} \mathrm{C}, 3 \mathrm{~min}$ at $72^{\circ} \mathrm{C}$, and $1 \mathrm{~min}$ at $96^{\circ} \mathrm{C}$ and a final extension for $20 \mathrm{~min}$ at $72^{\circ} \mathrm{C}$. Controls contained either $100 \mathrm{ng}$ of mouse genomic DNA or no template. PCR products were resolved on $1 \%$ agarose gels. The $390 \mathrm{bp}$ amplicon deriving from P1 6386 DNA was gel-purified (Qiagen) and labeled with dUTP-conjugated digoxigenin (Boehringer Mannheim) by PCR according to the manufacturer's procedure and was used as a probe. For Southern blot hybridization, each $800 \mathrm{ng}$ of restriction-digested P1 DNA was size-fractionated on $0.6 \%$ agarose gels, denatured $(0.5 \mathrm{M}$ $\mathrm{NaOH}$ and $1.5 \mathrm{M} \mathrm{NaCl}$ ), and neutralized $(3 \mathrm{M} \mathrm{NaCl}$ and $0.5 \mathrm{M}$ Tris- $\mathrm{HCl}$, $\mathrm{pH}$ 7.5) before passive overnight transfer onto nylon membranes (Nytran; Bio-Rad, Hercules, CA). The membranes were UV-cross-linked $\left(120 \mathrm{~mJ} / \mathrm{cm}^{2}\right.$; UV Stratalinker 2400; Stratagene), prehybridized for $2 \mathrm{hr}$ at $62^{\circ} \mathrm{C}$ in $5 \times \mathrm{SSC}, 0.1 \% \mathrm{~N}$-lauroylsarkosine, $0.02 \% \mathrm{SDS}$, and $1 \%$ blocking reagent (Boehringer Mannheim), and hybridized for $16 \mathrm{hr}$ at $62^{\circ} \mathrm{C}$ in the same buffer containing $25 \mathrm{ng}$ of digoxigenin-labeled DNA probe (see above). Posthybridization washes were $10 \mathrm{~min}$ in $2 \times \mathrm{SSC}$ at room temperature and twice for $30 \mathrm{~min}$ each in $0.2 \times$ SSC containing $0.1 \%$ SDS at $65^{\circ} \mathrm{C}$. Detection of digoxigenin-labeled hybridization products was performed using the manufacturer's protocol (DIG-Genius Users Guide; Boehringer Mannheim). The $3 \mathrm{~kb} X b a \mathrm{I}$ hybridization fragment was subcloned into pGEM5zf (Promega) and subjected to double-strand sequencing. The $O R-Z 6$ sequence was deposited in GenBank (accession number AF320347).

Genomic Southern blot hybridization. Genomic DNA was extracted from liver tissue of H-lacZ6 and wild-type mice (129S3), subjected to restriction digestion, and size-fractionated on $0.6 \%$ agarose gels. Southern blotting and hybridization conditions were as described. The DNA probe, the digoxigenin-dUTP-labeled $899 \mathrm{bp}$ fragment of the OR-Z6 coding region, was generated by PCR using primers $\mathrm{N}$ and $\mathrm{C}$.

Bacterial artificial chromosome clones. The sequence of the $629 \mathrm{bp}$ flanking fragment (see above) was used to screen The Institute for Genomic Research (TIGR) database that contains the sequenced ends of EcoRI-digested mouse genomic DNA [C57BL/6J female mouse bacterial artificial chromosome (BAC) end sequence (BES)] generated by Osoegawa et al. (2000). BAC clones RPCI-23-282I16 (AQ932615) and RPCI23-323H21 (AQ988378) were obtained as stab cultures (CHORI; BACPAC Resources, Oakland, CA) and amplified in LB medium containing $20 \mu \mathrm{g} / \mathrm{ml}$ chloramphenicol (Sigma). Purification of BAC DNA and subsequent conditions for PCR using the degenerate primers NL61 and NL63 were as described for P1 DNA using annealing temperatures of $50^{\circ} \mathrm{C}$ (high stringency) or $40^{\circ} \mathrm{C}$ (low stringency). PCR products were size-fractionated on agarose gels, gel-purified, and subcloned into the pGEM-T vector system (Promega). Generated subclones were analyzed by restriction digestion and sequencing.

Primers used ( $5^{\prime}$ to $3^{\prime}$ orientations). The following primers were used: EW1, TGTCTGGATCCAGATGGAGG; EW20, CGATAAGCTCGATATCGA; ps2, CAGTCCTGCAGTAGTGAATTCTC; ps4, CAGTGTTTTGTATTCCTTCTCAG; p26, GCITA(T/C)GA(T/C)CGITA(T/C) GTIGCIATITG; p27, ACIACIGAIAG(A/G)TGIGAI $(\mathrm{C} / \mathrm{G}) \mathrm{C}(\mathrm{A} / \mathrm{G})$ CAIGT; NL61, CGGAATTCCC(G/A/T/C)ATGTA(C/T) (C/T)T(G/A/ T/C)TT(C/T)CT;NL63,ATAAGCTTAG(G/A)TG(G/A/T/C)(G/C)(T/A) $(\mathrm{G} / \mathrm{A} / \mathrm{T} / \mathrm{C})(\mathrm{G} / \mathrm{C}) \mathrm{C}(\mathrm{G} / \mathrm{A}) \mathrm{CA}(\mathrm{G} / \mathrm{A} / \mathrm{T} / \mathrm{C}) \mathrm{GT}$; and $O R-Z 6$ gene-specific primers (coding region) N, CCTGGATCCCAAGAGCTACAC (48-69 bp, sense), and C, CTGAGGAGCAGACAGCAACGC (918-938 bp, antisense).

Reverse transcription-PCR for OR-Z6. Four-week-old 129S3/SvImJ mice (129S3; The Jackson Laboratory, Bar Harbor, ME) were decapitated; their tissues (OE, OBs, and liver) were dissected and snap-frozen in liquid nitrogen. Total RNA was extracted with RNAzol-B (TELTEST, Friendswood, TX). Contaminating genomic DNA was removed by DNase I digestion ( $2 \mathrm{U}$ of DNase I/ $\mu \mathrm{g}$ of RNA; Boehringer Mannheim), followed by acidic phenol/chloroform extraction (Ambion, Austin, TX). Total RNA was reverse transcribed (Superscript RTII; random hexamer primers, $20 \mathrm{pmol} / \mu \mathrm{g}$ of RNA; Life Technologies), and $500 \mathrm{ng}$ of cDNA was subjected to PCR. To control for PCR products deriving from amplification of residual genomic DNA, an aliquot of RNA from each 
tissue was subjected to PCR without preceding cDNA synthesis. OR-Z6 cDNA was selectively amplified using the gene-specific primers $\mathrm{N}$ and $\mathrm{C}$ that generate an $899 \mathrm{bp}$ fragment of the OR-Z6 coding region. PCR products were resolved on $1 \%$ agarose gels containing $0.5 \mu \mathrm{g} / \mathrm{ml}$ ethidium bromide, visualized under UV light, and photographed (Polaroid, Cambridge, MA). PCR products were gel-purified (Qiagen) and sequenced using primers $\mathrm{N}$ and $\mathrm{C}$.

Tissue preparation for cryostat sections. Three- to 6-week-old 129S3 mice (The Jackson Laboratory) or H-lacZ6 mice were anesthetized using ketamine at $165 \mathrm{mg} / \mathrm{kg}$ of body weight (Animal Health, Fort Dodge, IO) and xylazine at $11 \mathrm{mg} / \mathrm{kg}$ of body weight (Bayer, Shawnee, KS). Mice were transcardially perfused with ice-cold buffer-1 (0.1 M PIPES, $5 \mathrm{~mm}$ $\mathrm{MgCl}_{2}$, and $5 \mathrm{~mm}$ EGTA, $\mathrm{pH}$ 6.9) (Emson et al., 1990) followed by fixative $[4 \%(\mathrm{w} / \mathrm{v})$ paraformaldehyde in buffer-1]. OE and OBs were dissected, cryoprotected in $30 \%$ sucrose overnight at $4^{\circ} \mathrm{C}$, embedded in O.C.T. (Tissue-Tek, Torrance, CA), and frozen in a dry ice/acetone bath. Serial cryosections $(10-18 \mu \mathrm{m})$ of the OE and of the OBs were thawmounted onto slides (Superfrost-Plus; Fisher Scientific, Pittsburgh, PA) and air-dried. All analyses were performed on coronal sections (frontal and perpendicular to the anterior-to-posterior axis of the OBs).

Detection of $\beta$-galactosidase expression. Staining of perfused hemiheads or cryosections using the chromogenic substrate 5-bromo-4-chloro-3indolyl- $\beta$-D-galactopyranoside (X-gal) and $\beta$-galactosidase immunohistochemistry were as described in Cummings et al. (2000).

In situ hybridization. Serial coronal cryosections of the $\mathrm{OE}$ and $\mathrm{OB}$ were fixed for $10 \mathrm{~min}$ in $4 \%$ paraformaldehyde in PBS at $4^{\circ} \mathrm{C}$, rinsed twice in PBS, and incubated for $10 \mathrm{~min}$ at room temperature in $0.25 \%$ acetic anhydride and $0.1 \mathrm{~m}$ triethanolamine, $\mathrm{pH}$ 8.0. Sections were rinsed in PBS and prehybridized in standard hybridization solution $(50 \%$ formamide, $5 \times$ SSC, $5 \times$ Denhardt's, $0.2 \%$ SDS, $0.5 \mathrm{mg} / \mathrm{ml}$ salmon sperm DNA, and $0.25 \mathrm{mg} / \mathrm{ml}$ yeast tRNA) for $4 \mathrm{hr}$ at $60^{\circ} \mathrm{C}$. OR-Z6 riboprobes were generated from a BamHI subclone in pGEM5zf(+) (Promega) containing a $573 \mathrm{bp}$ fragment of the $O R-Z 6$ coding region. Digoxigeninlabeled $O R-Z 6$ sense and antisense riboprobes were prepared from $1 \mu \mathrm{g}$ of the linearized subclone ( $X b a \mathrm{I}$ and EcoRI, respectively) using the T7/Sp6 RNA transcription system (DIG-Genius Users Guide; Boehringer Mannheim). OR37E riboprobes were prepared similarly; the plasmid (generously provided by J. Strotmann) was first linearized using PstI or ApaI restriction enzymes. Blunt ends were obtained by incubation with Klenow enzyme (Promega), and sense and antisense riboprobes were generated using the kit indicated above. Riboprobes for the OB were prepared accordingly, but CTP was replaced by $12 \mu \mathrm{M}\left[\alpha^{-}{ }^{32} \mathrm{P}\right] \mathrm{CTP}(10$ $\mathrm{mCi} / \mathrm{ml}$; >3000 Ci/mmol; Amersham Pharmacia Biotech). Hybridization of $\mathrm{OE}$ sections was performed at $60^{\circ} \mathrm{C}$ for $16 \mathrm{hr}$ in standard hybridization solution containing $500 \mathrm{ng} / \mathrm{ml}$ digoxigenin-labeled sense or antisense RNA probes. Hybridization of OB sections was performed similarly using $1 \times 10^{8} \mathrm{cpm} / \mathrm{ml}\left[\alpha^{-32} \mathrm{P}\right] \mathrm{CTP}$-labeled riboprobe containing $10 \%$ dextran sulfate (molecular weight, 500,000). After hybridization, sections were washed twice for $5 \mathrm{~min}$ each in $4 \times \mathrm{SSC}$ at room temperature and treated with RNase A (500 mM NaCl, $10 \mathrm{~mm}$ Tris- $\mathrm{HCl}, 1 \mathrm{~mm}$ EDTA, and $5 \mu \mathrm{g} / \mathrm{ml}$ RNase A, $\mathrm{pH} 7.5$ ) for $30 \mathrm{~min}$ at $37^{\circ} \mathrm{C}$. Sections were washed twice for $10 \mathrm{~min}$ each in $2 \times \mathrm{SSC}$ at room temperature, twice for $30 \mathrm{~min}$ each in $0.2 \times \mathrm{SSC}$ at $60^{\circ} \mathrm{C}$, and once for $30 \mathrm{~min}$ in $0.1 \times \mathrm{SSC}$ at $60^{\circ} \mathrm{C}$. Sections hybridized with the $\left[\alpha{ }^{3}{ }^{32} \mathrm{P}\right] \mathrm{CTP}-$ labeled riboprobe were dehydrated in increasing percentages of ethanol, dipped into NTB-3 photo emulsion (Kodak, New Haven, CT), and air-dried. After a 4 week exposure in the dark at $4^{\circ} \mathrm{C}$, sections were developed in Kodak-D19 (2 min at $16^{\circ} \mathrm{C}$ ), rinsed in water, fixed in Kodak fixer, counterstained with hematoxylin (Sigma), dehydrated in ethanol, and cleared in xylene, and coverslips were mounted with DPX (Aldrich, Milwaukee, WI,). Sections hybridized with a digoxigenin-labeled riboprobe were blocked in TBS $(0.1 \mathrm{M}$ Tris- $\mathrm{HCl}$ and $0.15 \mathrm{M} \mathrm{NaCl}, \mathrm{pH} 7.5)$ containing $4 \%$ goat serum, and hybridization products were detected using alkaline phosphataseconjugated sheep anti-digoxigenin antibody (Boehringer Mannheim; 1:5000 in TBS; overnight at $4^{\circ} \mathrm{C}$ ) and washed twice for $15 \mathrm{~min}$ each in TBS. Bound antibody was visualized using 5-bromo-4-chloro-3-indolylphosphate/nitroblue tetrazolium (Boehringer Mannheim) as substrate, yielding a cytosolic purple precipitate. Endogenous alkaline phosphatase activity was blocked with $0.24 \mathrm{mg} / \mathrm{ml}$ Levamisol (Sigma). Color development was stopped in TE buffer $(20 \mathrm{~mm}$ Tris- $\mathrm{HCl}$ and $5 \mathrm{~mm}$ EDTA, pH 8.0), and the sections were coverslipped in Dako mounting medium (Dako, Carpinteria, CA).

Zonal tracing. Adjacent coronal cryosections from P19 wild-type mice (129S3; The Jackson Laboratory) were collected on separate sets of slides, and each set was subjected to in situ hybridization using sense and antisense riboprobes either for $O R-Z 6$ or for one of the OR genes shown previously to represent a single rostrocaudal zone of the OE. Clones for generating riboprobes for $K 21$ (zone 1), $K 20$ (zone 2), and L45 (zone 3) were kindly provided by L. Buck (Ressler et al., 1993, 1994). Digoxigeninlabeled riboprobes were prepared as described above. In situ hybridization signals for each OR mRNA were subsequently traced using a camera lucida attached to a Leitz Orthoplan microscope (Leitz, Wetzlar, Germany). The individual maps obtained for $O R-Z 6, K 20, K 21$, and $L 45$ were color-coded and scanned, and the images were stacked to facilitate comparison.

Preparation of photographs. Photographs of olfactory turbinates and OB whole mounts stained with X-gal were taken on a Leica WILD M3Z dissecting photomicroscope (Leica, Deerfield, IL) using Ektachrome $160 \mathrm{~T}$ slide film (Kodak). Images were digitized using a Nikon LS-1000 slide scanner (Nikon, Melville, NY). Light photomicrographs were scanned on a Leica DMRX microscope attached to a Phase One Power Phase digital camera (Phase One, Copenhagen, Denmark). Photomicrographs of radioactive in situ hybridization were taken with a dark-field condenser using a Nikon Optiphot-2 microscope (Nikon) fitted onto a Polaroid DMC1 digital camera (Polaroid). Digitized images were minimally processed (adjustments included only small changes in contrast and brightness) using Adobe Photoshop 5.0 (Adobe Systems, Mountain View, CA), and photomicrographs were printed on a Fujix Pictrography 3000 (Fuji, Carlstadt, NJ).

\section{RESULTS}

The transgene expression pattern in the $\mathrm{OE}$ of $\mathrm{H}-\mathrm{lacZ} 6$ mice (Walters et al., 1996a) was analyzed by staining whole-mount nose preparations using the chromogenic substrate X-gal. As seen for the in situ hybridization patterns reported for some OR genes (Ressler et al., 1993; Vassar et al., 1993; Strotmann et al., 1994a,b), transgene expression in H-lacZ6 mice was limited to a subset of ORNs (Fig. $1 A$ ). In agreement with our previous studies (Treloar et al., 1996; Walters et al., 1996a), $\beta$-galactosidasepositive $\left(\beta-\mathrm{gal}^{+}\right)$neurons appear in a zonal pattern along the anterior-to-posterior axis of the $\mathrm{OE}$ and exhibit a high density on endoturbinate-II. On the basis of this expression pattern, we hypothesized that the lac $Z$ transgene had integrated at a locus that directs the expression of nearby OR genes. To address this and to obtain information about genomic sequences flanking the transgene locus, we screened an $\mathrm{H}$-lacZ6 mouse genomic library in $\lambda$ DashII using a ${ }^{32} \mathrm{P}$-labeled lacZ DNA probe. Analyses of the positive phages enabled us to identify and subclone a genomic flanking fragment of $629 \mathrm{bp}$ (clone pBSKS3'-flank) that resides immediately downstream of the transgene construct. This $3^{\prime}-$ flanking fragment was subsequently used to determine the chromosomal localization of the transgene as well as to isolate the corresponding genomic region from a wild-type mouse genomic library in P1 phagemids.

\section{The lacZ transgene maps to mouse chromosome 6}

As a first step toward understanding the transgene locus $(\mathrm{HlzG})$, we mapped the chromosomal location of the insertion site by interspecific backcross analysis using a panel that has been typed for over 2900 loci that are well distributed among all autosomes and the X chromosome (Copeland and Jenkins, 1991). DNA from C57BL/6J and M. spretus was analyzed for informative RFLPs using the $629 \mathrm{bp}$ genomic $3^{\prime}$-flanking fragment as a probe. The mapping results indicated that the Hlz6 locus is located in the proximal region of mouse chromosome 6 and linked to the chromosomal markers Ptn, Tcrb, and Hoxa5. We analyzed 174 mice for every marker (Fig. $1 B$ ) and up to 193 mice for some pairs of markers. Each locus was analyzed in pair-wise combinations for recombination frequencies using the additional data. The ratios of the total number of mice exhibiting recombinant chromosomes to the total number of mice analyzed for each pair of loci showed 


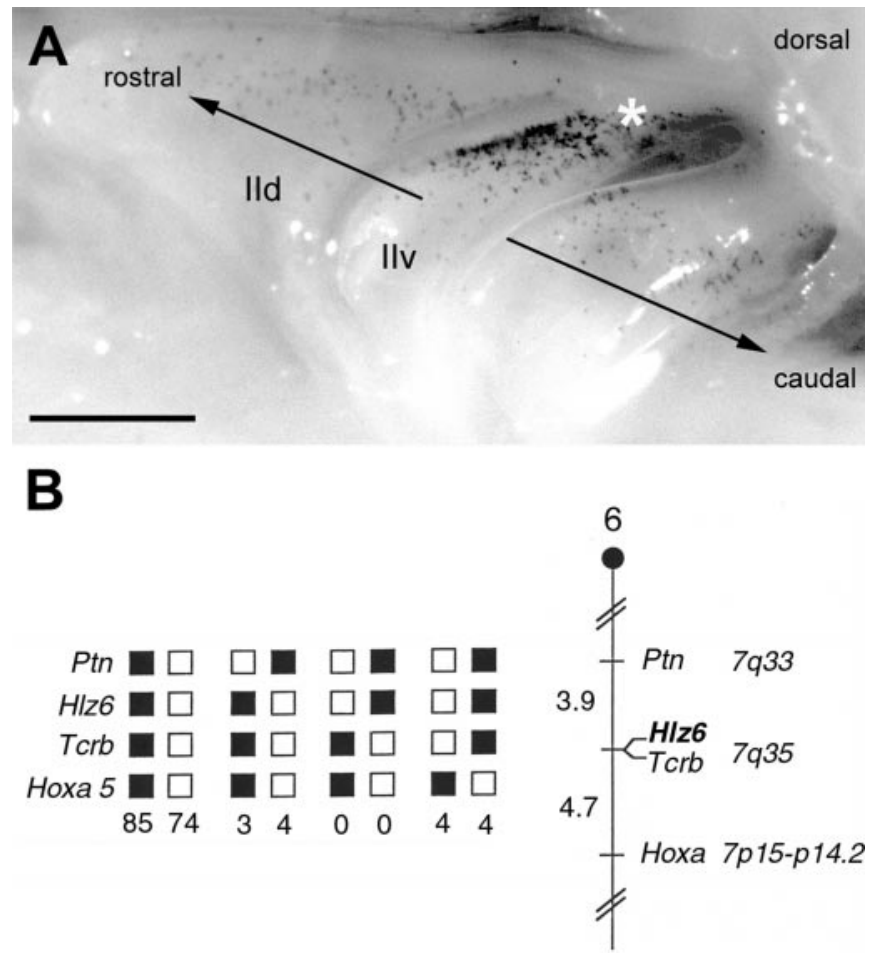

Figure 1. Expression pattern and chromosomal location of the $O M P-$ lacZ transgene in $\mathrm{H}$-lacZ6 mice. A, X-gal staining in the right heminose of a 3-week-old H-lacZ6 mouse is shown. The punctate pattern shown corresponds to the ORN subpopulation expressing the lac $Z$ transgene (black dots). The majority of $\beta$-gal ${ }^{+}$neurons is concentrated on endoturbinate-IIv (star); fewer neurons are scattered along the rostrocaudal axis of the OE (arrows). Endoturbinate-IId and -IIv, Dorsal and ventral aspects of endoturbinate-II. Scale bar, $1 \mathrm{~mm}$. $B$, The transgene insertion site in $\mathrm{H}$-lacZ6 mice (Hlz6 locus) maps to the proximal region of mouse chromosome 6 , as determined by interspecific backcross analysis. Left, The segregation patterns of Hlz6 and the flanking genes (Ptn, Tcrb, and Hoxa5) were typed in 174 backcross animals. For individual pairs of loci, $>174$ animals were typed (see text). Each column represents the chromosome identified in the backcross progeny that was inherited from the $\mathrm{C} 57 \mathrm{BL} / 6 \mathrm{~J} \times M$. spretus $\mathrm{F} 1$ parent. The black and white boxes refer to the presence of a $\mathrm{C} 57 \mathrm{BL} / 6 \mathrm{~J}$ allele and an $M$. spretus allele, respectively. The number of offspring inheriting each type of chromosome is listed at the bottom of each column. Right, A partial chromosome 6 linkage map shows the location of Hlz6 in relation to its linked genes. Recombination distances between loci in centimorgans are shown to the left of the chromosome, and the positions of loci in human chromosomes, where known, are shown to the right. References for the human map positions of loci cited in this study can be obtained from the Genome Data Base, a computerized database of human linkage information maintained by The William H. Welch Medical Library of The Johns Hopkins University (Baltimore, MD).

that the most likely gene order is the following: centromere-Ptn7/181-Hlz6-0/186-Tcrb-9/193-Hoxa5. The recombination frequencies [expressed as genetic distances in centimorgans $(\mathrm{cM}) \pm$ the SE] are the following: Ptn-3.9 $\pm 1.4 \mathrm{cM}-H \mathrm{~Hz} 6, \mathrm{Tcrb}-4.7 \pm 1.5$ cM-Hoxa5. No recombinants were detected between $\mathrm{Hlz} 6$ and Tcrb in 186 animals typed in common, suggesting that the two loci are within $1.6 \mathrm{cM}$ of each other. We compared our interspecific map of chromosome 6 with a composite mouse linkage map that reports the location of many uncloned mouse mutations (Mouse Genome Database; The Jackson Laboratory). Hlz6 mapped in a region that lacks mouse mutations with a phenotype that might be expected for an alteration in this locus (data not shown). The proximal region of mouse chromosome 6 shares regions of ho- mology with both the long and short arms of human chromosome 7 (Fig. $1 B$ ). In particular, Tcrb has been mapped to $7 \mathrm{q} 35$. The close linkage between Hlz6 and Tcrb in mouse suggests that the human homolog of the $\mathrm{Hlz6}$ locus will map to 7q as well.

\section{Cloning of the new mouse OR gene OR-Z6}

To search the vicinity of the Hlz6 locus for the presence of OR genes, we first isolated the genomic region surrounding the Hlz6 locus from a wild-type mouse genomic library in $\mathrm{P} 1$ phagemids by PCR, using primers ps 2 and ps 4 that derived from the sequence of the $3^{\prime}$-flanking fragment. Four genomic P1 clones (P1 clones 6386-6389; Genome Systems) with an average insert size of $80 \mathrm{~kb}$ were obtained and confirmed to correspond to the transgene integration site by PCR using the same primers (Fig. $2 A$ ). The existence of OR genes at the Hlz6 locus was assessed by subjecting the four P1 clones to PCR using the degenerate oligonucleotides p26 and p27, shown previously to amplify the region between transmembrane domains 3 and 6 of human and mouse OR genes (nucleotide sequences for p26 and p27 were provided by L. Buck) (Ngai et al., 1993). One of the clones, P1 6386, gave rise to a PCR product of the expected size of $390 \mathrm{bp}$ (Fig. 2A). Assuming that this amplicon represents a mixture of different OR sequences, the PCR product was labeled with digoxigenin and used as a probe in Southern blot hybridization of restriction-digested P1 6386 DNA (Fig. 2B). The number of detected hybridization products per digestion indicated that one potential OR gene was obtained by PCR. Subcloning and sequence analysis of a $3 \mathrm{~kb}$ hybridizing $X b a$ I fragment (Fig. $2 B$ ) led indeed to the identification of a new mouse OR gene that we named $O R-Z 6$, recalling its identification in the genomic context of the mouse line H-lacZ6. The intronless open-reading frame of $O R-Z 6$ encodes a typical G-protein-coupled, seven transmembrane domain protein and contains many conserved amino acid motifs and single residues in specific positions characteristic of the large family of OR genes (Fig. 3A). This analysis demonstrated that the transgene construct in $\mathrm{H}-\mathrm{lacZ} 6$ mice had indeed inserted close to an OR gene. OR-Z6 is the first cloned OR gene that maps to mouse chromosome 6 .

\section{OR-Z6 orthologs on human chromosome 7}

Subsequent homology searches in the European Molecular Biology Laboratory database using the deduced OR-Z6 protein showed sequence similarities up to $66 \%$ with other OR genes but did not reveal any $O R-Z 6$ homologs. Interestingly, when searching the High Throughput Genomic Sequences human genome database, we identified OR genes on human chromosome 7 that have a higher homology to $O R-Z 6$ than to any other OR sequence yet reported and most likely represent human $O R-Z 6$ orthologs. $\mathrm{Hu}-$ man clone RP11-707F14 (AC073647) carries three OR-Z6 orthologs, the coding regions of which show $81-94 \%$ nucleotide sequence identity among themselves and $78-81 \%$ identity with the mouse $O R-Z 6$ gene. One of the human ORs shares $85 \%$ amino acid similarity with $O R-Z 6$ (Fig. $3 A$ ), whereas the deduced protein sequences of the other two $O R-Z 6$ orthologs are interrupted by frame shifts and stop codons that may reflect pseudogenes or the draft quality of the sequence released. Consistent with previous reports (Ben-Arie et al., 1994; Asai et al., 1996; Sullivan et al., 1996; Trask et al., 1998; Strotmann et al., 1999; Tsuboi et al., 1999), the human $O R-Z 6$ orthologs exist in a tandem array and are separated by 31 and $24 \mathrm{~kb}$ spacers.

\section{OR-Z6 is a single OR gene at the HIz6 locus}

To identify mouse OR-Z6 homologs, we performed highstringency genomic Southern blot hybridization using a 

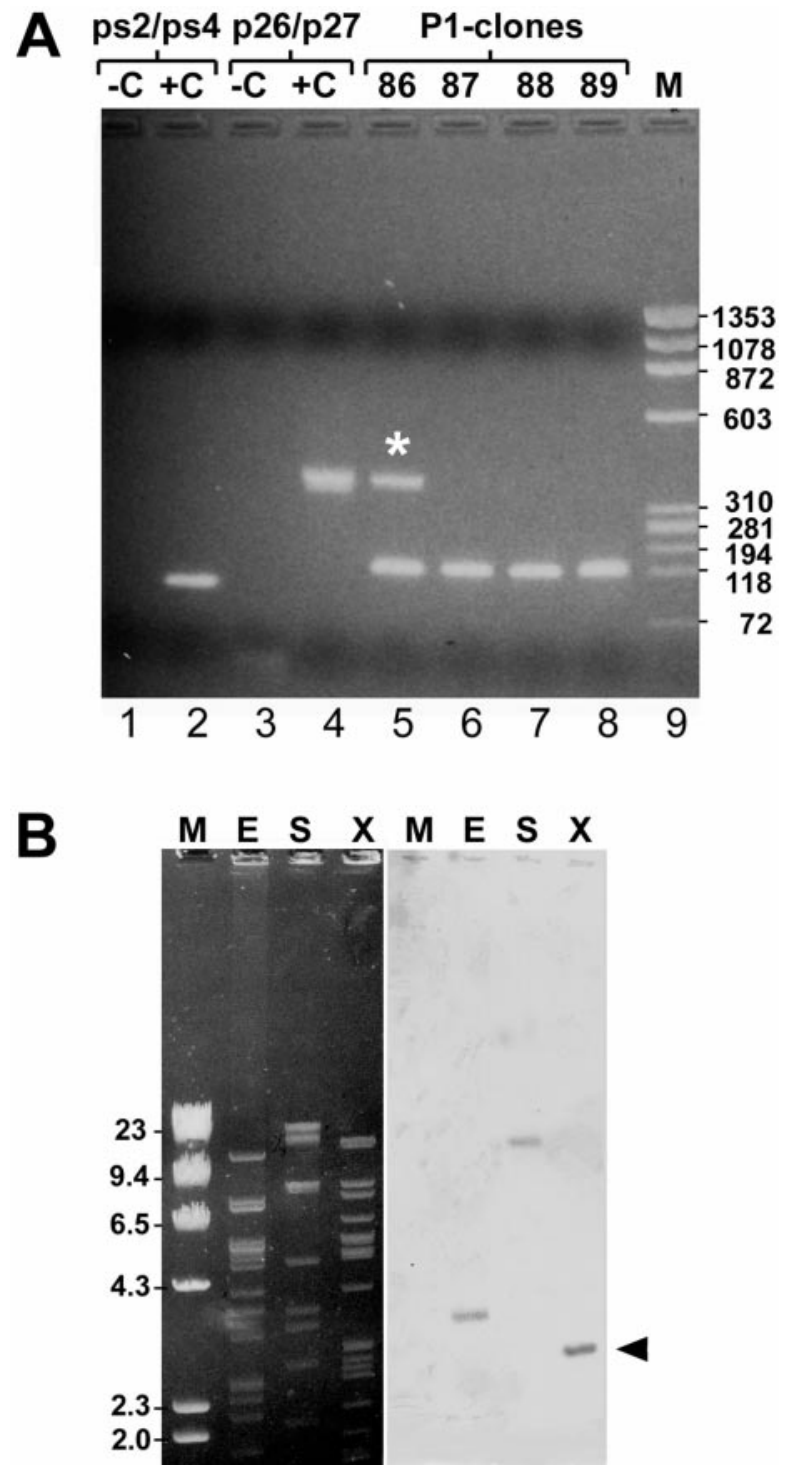

Figure 2. Identification of the new odorant receptor gene $O R-Z 6$ at the Hlz6 locus. A, Gel electrophoresis is shown of the products obtained after PCR of the four P1 clones 6386-6389 (lanes 5-8) using the two different primer sets primers p26 and p 27 and primers ps 2 and ps4. All P1 clones carry the $3^{\prime}$-flanking fragment as demonstrated by the $160 \mathrm{bp}$ amplicon derived from primers ps2 and ps4 (lanes 5-8). The 390 bp PCR product (star) derived from the degenerate OR primers p26 and p27 is only evident for P1 clone 6386 (lane 5) and the positive control ( $+C$, lane 4) using mouse genomic DNA. The thickness of the band in the positive control (lane 4 ) reflects the amplification of numerous genomic OR genes. The positive control for primers ps 2 and ps4 $(+C$, lane 2 ; mouse genomic DNA) shows a 160 bp amplicon, whereas negative control reactions, omitting template DNA, yielded no products for primers ps2 and ps4 $(-C$, lane 1$)$ or primers p26 and p27 ( - C, lane 3$)$. HaeIII-digested $\Phi$ X174 phage DNA $(M)$ is the length standard (lane 9). Fragment sizes in base pairs are indicated by the numbers at the right. $B$, Restriction digestion (left) followed by Southern blot hybridization (right) shows that the P1 clone 6386 carries a single OR gene. Eight hundred nanograms of each P1 6386 DNA digest ( $E, E c o$ RI; $S, S a c \mathrm{I} ; X, X b a \mathrm{I})$ were resolved on a $0.6 \%$ agarose gel, transferred onto a nylon membrane, and subjected to Southern blot hybridization. The probe was prepared by labeling the $390 \mathrm{bp}$ PCR fragment obtained in $A$ with digoxigenin-conjugated dUTP via PCR using primers p26 and p27. Hybridizing fragment sizes were $4 \mathrm{~kb}$ (EcoRI), $11 \mathrm{~kb}(S a c \mathrm{I})$, and $3 \mathrm{~kb}(X b a \mathrm{I})$. The $3 \mathrm{~kb}$ hybridizing $X b a \mathrm{I}$ fragment (arrowhead) was subcloned and sequenced. HindIII-digested $\lambda$ DNA $(M)$ is the length standard in kilobase pairs indicated by the numbers at the left. digoxigenin-labeled DNA probe of the $O R-Z 6$ coding region and genomic DNA from both wild-type mice (129S3) and H-lacZ6 mice. It has been reported that members of a subfamily share at least $80 \%$ identity and cross-hybridize with one another (Lancet and Ben-Arie, 1993). The identical hybridization patterns obtained from both DNA types (Fig. 3B) implied that the integration of the lac $Z$ transgene did not delete or grossly modify the OR-Z6 locus in H-lacZ6 mice. Furthermore, the number of the hybridizing fragments obtained per digestion showed that $O R-Z 6$ in mouse is most likely a single gene in its subfamily but does not exclude the possibility that OR genes from a different subfamily reside proximal to the $O R-Z 6$ gene. To address this question, we analyzed two BAC clones that extend $\sim 190 \mathrm{~kb}$ each upstream and downstream of the Hlz6 locus. The terms "upstream" and "downstream" refer to the 3 '-flanking fragment that maps downstream of the transgene construct in $\mathrm{H}-\mathrm{lacZ} 6$ mice and were only defined for the purpose of orientation. A computerized search in an end-sequenced mouse genomic BAC library (TIGR database) using the $3^{\prime}$-flanking fragment as a query yielded two BAC clones. Clones RPCI-23-282I16 (AQ932615) and RPCI-23323H21 (AQ988378) showed 96\% identity with the first $348 \mathrm{bp}$ and the last $250 \mathrm{bp}$ of the $3^{\prime}$-flanking fragment, respectively. Thus, the sequence of our transgene $3^{\prime}$-flanking fragment overlaps the two BAC clones and links them into a single contig. PCR analyses of both BAC clones, using the degenerate primers NL61 and NL63 that amplify the region between transmembrane domains 2 and 6 of OR genes (primer sequences were obtained from R. Reed, The Johns Hopkins University), yielded no other OR genes in addition to OR-Z6. Low-stringency PCR yielded PCR products from both BAC clones that were subcloned. A total of 55 subclones derived from both BAC clones were examined by restriction digestion, and 20 of these clones were subjected to sequence analysis (data not shown). No OR genes were identified on BAC PCI-23-323H21 that extends downstream of the Hlz6 locus. All sequenced subclones deriving from BAC RPCI-23282I16 that extends upstream of the $H l z 6$ locus were identical to the $O R-Z 6$ sequence. Thus, $O R-Z 6$ in mouse may be a single OR gene at the Hlz6 locus or the last member of a cluster that resides even farther upstream in a region not covered by BAC RPCI-23-282I16.

\section{OR-Z6 expression in the OE}

The tissue-specific expression of $O R-Z 6$ was addressed by reverse transcription (RT)-PCR in three different tissues using the genespecific primers $\mathrm{N}$ and $\mathrm{C}$ (Fig. $3 A$ ) that span 899 bp of the $O R-Z 6$ coding region. Amplicons of the expected size were only obtained after RT-PCR using RNA from OE and OB (Fig. 3C), demonstrating that $O R-Z 6$ is an expressed OR gene and that its mRNA is present in olfactory tissue. No products were obtained from liver RNA or control reactions that omit reverse transcriptase during cDNA synthesis. Sequencing of the RT-PCR products showed that they were identical to the $O R-Z 6$ sequence, initially derived from the genomic $X b a \mathrm{I}$ subclone.

To analyze the distribution of $O R-Z 6$ mRNA in the OE, we performed in situ hybridization of serial coronal cryosections along the anterior-to-posterior axis using digoxigenin-labeled antisense and sense riboprobes. Riboprobes were generated from a subcloned BamHI fragment that spans the region between transmembrane domains 1 and 5 of the $O R-Z 6$ coding region (Fig. $3 A$, top, restriction map). Hybridizing ORNs were predominantly located in the mid-to-caudal aspects of the OE. Interestingly, OR$\mathrm{Z6}^{+}$ORNs were strongly restricted to the medial epithelial 
Figure 3. The new mouse $O R-Z 6$ gene encodes a typical OR protein. $A$, Top, Partial restriction map of the $3 \mathrm{~kb} X b a \mathrm{I}$ fragment carrying the complete $O R-Z 6$ coding region (black box) and sequences $1.2 \mathrm{~kb}$ upstream and $1 \mathrm{~kb}$ downstream. Location of the gene-specific primers $\mathrm{N}$ and $\mathrm{C}$ used in RT-PCR analyses $(C)$ is indicated by arrows. Restriction enzymes are the following: $B, B a m \mathrm{HI} ; E$, EcoRI; S, SphI; X, XbaI. Bottom, Comparison of the deduced amino acid sequences of the coding regions of mouse OR-Z6 (mOR-Z6) and a human OR-Z6 ortholog $(h O R-Z 6)$ in one-letter code. For $h O R-Z 6$, only differences from the mOR-Z6 sequence are shown. Gray shading depicts the predicted seven transmembrane domains $T M-1$ to $T M-7$. The amino acid sequence domains of the two OR-Z6 proteins that match closely to the motifs conserved (indicated by a horizontal line) among OR proteins are PMYFFL (TM-2), MAVDRYVAVC (TM-3), SY (TM-5), K (A/S)FSTCASH (TM-6), and PFLNPF (TM-7). Both OR-Z6 proteins share $85 \%$ similarity over a total of 314 amino acids and exhibit cysteine residues in conserved positions $(97,179$, stars $)$ and a putative $\mathrm{N}$-terminal receptor glycosyl-

A
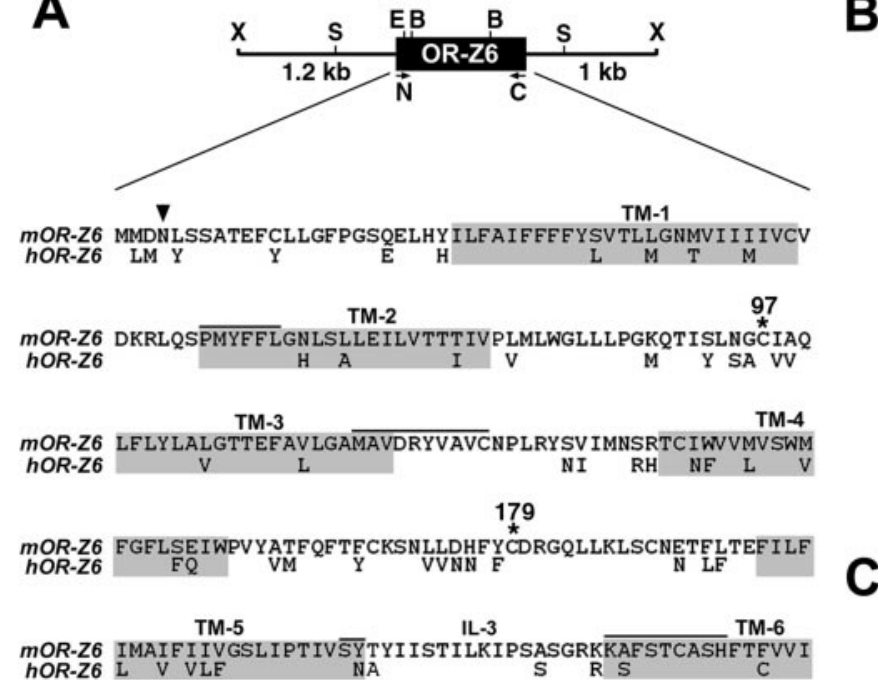

TM-7

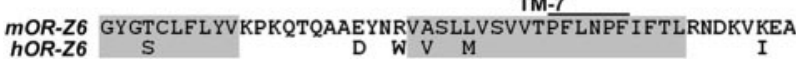

$\underset{\text { hOR-Z6 LRDGVKRCCLLLRD }}{\text { MOR }}$
B
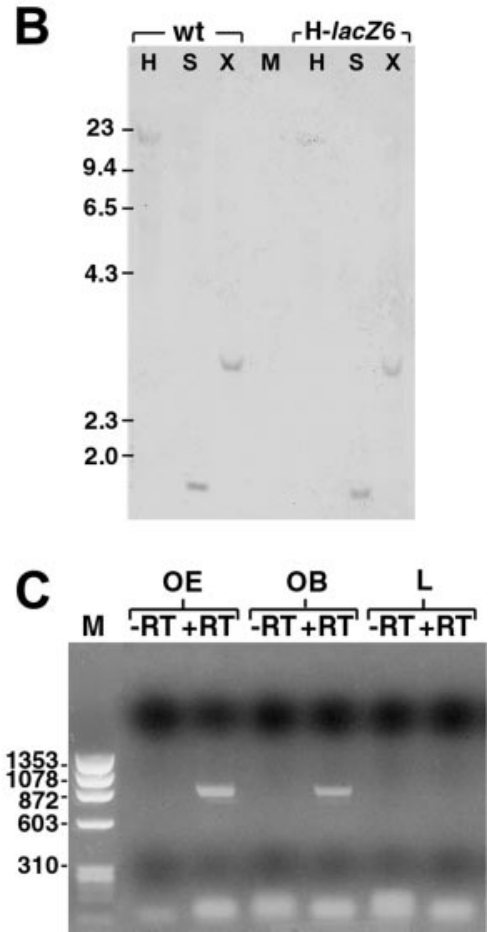

ation site (arrowhead), as well as several serine and threonine phosphorylation sites in the third intracellular loop (IL-3). B, Genomic Southern blot hybridization for OR-Z6. Restriction digestion of mouse liver DNA (10 $\mu \mathrm{g} /$ lane) from wild-type (wt) and H-lacZ6 mice was as indicated (H, HindIII; $S, S p h \mathrm{I} ; X, X b a \mathrm{I})$. The Southern blot was hybridized with the digoxigenin-labeled $O R-Z 6$ coding region. The DNA probe hybridized to a single fragment per lane, and the sizes of the hybridizing fragments for both wild-type and H-lacZ6 genomic DNA were identical (H, $23 \mathrm{~kb} ; S, 1.72 \mathrm{~kb} ; X, 3 \mathrm{~kb})$. HindIII-digested $\lambda$ DNA $(M)$ is the length standard in kilobase pairs indicated by the numbers on the left. $C$, RT-PCR performed with RNA from three different tissues demonstrating that $O R-Z 6 \mathrm{mRNA}$ is expressed in olfactory tissues $(O E, O B)$. The photograph shows a gel electrophoresis of the products derived from RT-PCR using the $O R-Z 6$ specific primers N and C. The 899 bp amplicon was only evident in samples with preceding reverse transcription $(+R T)$. No products were obtained from RT-PCR using liver mRNA $(L)$ or from reactions omitting reverse transcriptase $(-R T)$. The lower intensity of the fragment obtained from OB mRNA versus that from OE mRNA coincides with reports demonstrating that OR mRNA is much less abundant in axon terminals compared with their cell bodies (Ressler et al., 1994).

recess, consisting of the tips of endoturbinate-II and -III and ectoturbinate-3, all of which are exposed at the central lumen of the nasal cavity (Fig. 4, left column). Within this zone, OR-Z6 ${ }^{+}$ neurons were randomly distributed as indicated by hybridization of single neurons and small clusters of approximately two to three neurons. $\mathrm{OR}-\mathrm{Z} 6^{+}$neurons were evident throughout the depth of the $\mathrm{OE}$ and seemed only occasionally to segregate in the more apical OE. Few labeled neurons were found in other turbinates, the septum, or the vomeronasal organ (VNO) (data not shown). The VNO, an accessory olfactory system, mediates the detection of pheromones via specialized classes of pheromone receptors (Dulac and Axel, 1995; Herrada and Dulac, 1997; Matsunami and Buck, 1997; Ryba and Tirindelli, 1997; Leinders-Zufall et al., 2000). Although these receptors differ from the main ORs, occasional cross-hybridization of VNO neurons with OR sequences has been reported (Dulac and Axel, 1995; Ebrahimi et al., 2000). We never detected hybridization signals in sustentacular cells, in olfactory stem cells, or in control hybridizations using the OR-Z6 sense probe. The $O R-Z 6$ hybridization pattern was essentially bilaterally symmetrical between the left and right nose and reproducible among the mice investigated $(n=10129 \mathrm{~S} 3$ mice). Comparison of the OR-Z6 mRNA pattern with that of three ORs, each known to represent a single rostrocaudal zone, further illustrated the divergent $O R-Z 6$ expression pattern (clones $K 21$, $K 20$, and $L 45$ corresponding to zones 1,2 , and 3 were provided by L. Buck). In situ hybridization for each of the four probes in adjacent cryosections, followed by manual tracing of the individ- ual mRNA patterns (data not shown), demonstrated that $O R-Z 6$ was not only confined to the medial aspect of zone 2 (according to the Buck nomenclature) (Ressler et al., 1993, 1994) but also overlapped with the ventral region of zone 1 and the dorsal aspect of zone 3. A similar restricted type of expression was reported for members of the OR37 subfamily in rat and mouse (Strotmann et al., 1992, 1999).

\section{Expression of $O R-Z 6$ and $\beta$-galactosidase in $\mathrm{H}-\mathrm{lacZ6}$ mice}

The $O R-Z 6$ expression pattern was strikingly similar to that of $\beta$-galactosidase in $\mathrm{H}$-lacZ6 mice. This became apparent when we compared the X-gal staining pattern in $\mathrm{H}$-lacZ6 mice with the OR-Z6 mRNA pattern in an age-matched wild-type mouse. Although $\beta$-gal ${ }^{+}$ORNs in $\mathrm{H}-$ lacZ6 mice were more numerous than $O R-Z 6^{+}$ORNs in wild-type mice, both patterns exhibited a high density of labeled neurons at the tips of the central turbinates (Fig. 4). $\mathrm{LacZ}^{+}$neurons were evident throughout the depth of the $\mathrm{OE}$ and did not exhibit obvious laminar segregation. As seen for $O R-Z 6$, a few $\beta$-gal ${ }^{+}$neurons were present in other turbinates, the septum, and the VNO (data not shown). Analyses of the rostrocaudal distribution in $\mathrm{H}$-lacZ6 mice further demonstrated the related expression patterns of $\beta$-galactosidase and $O R-Z 6$ (Fig. 5). Adjacent coronal cryosections from H-lacZ6 mice were collected as separate sets of every 10th section and subjected to either X-gal staining or OR-Z6 in situ hybridization before the labeled cells were counted. On the basis of the similar expression 


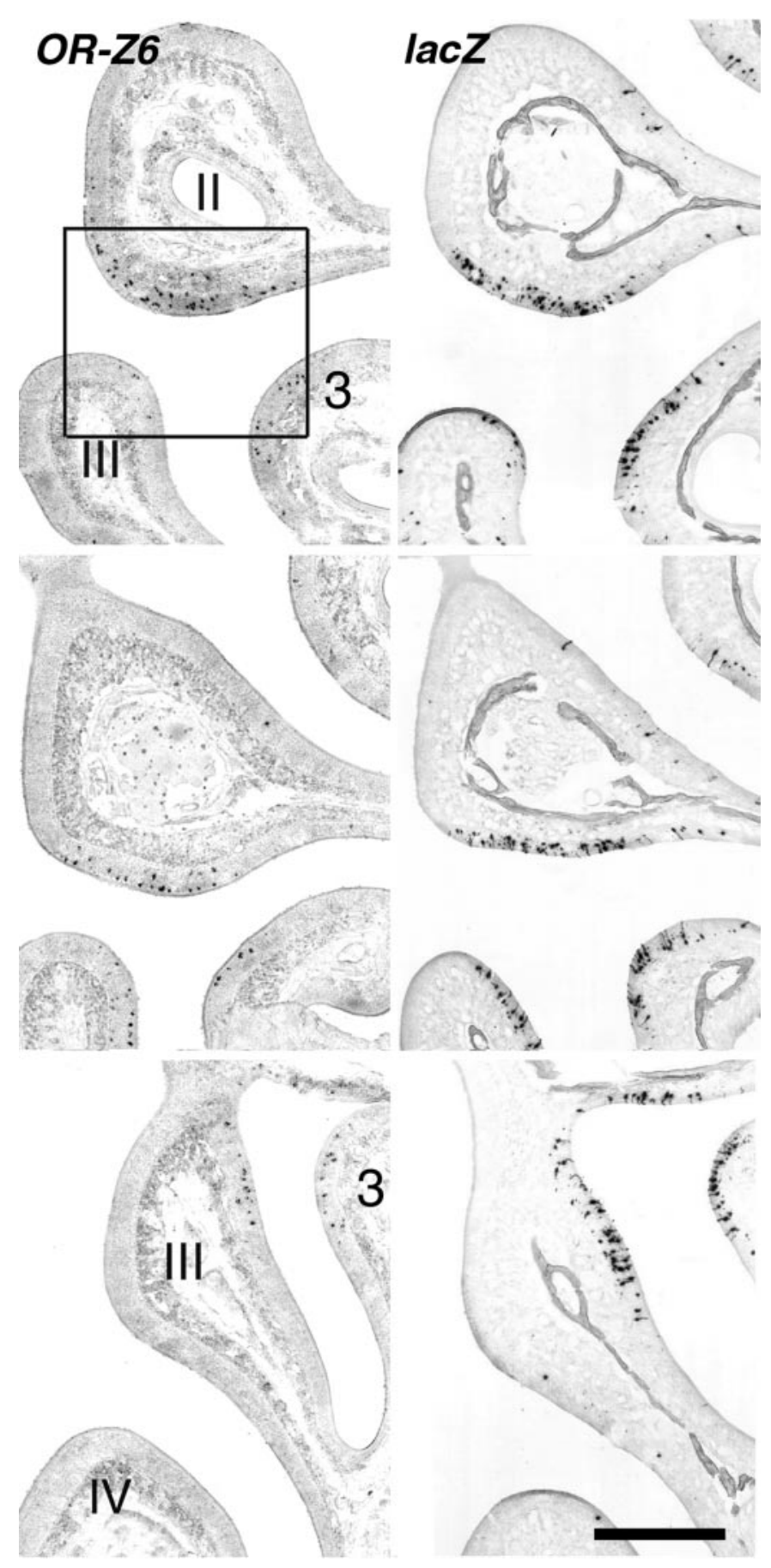

Figure 4. OR-Z6 mRNA and $\beta$-galactosidase exhibit similar expression patterns in mouse OE. The hemisections (left nostril) shown in both columns represent a survey from anterior (top) to posterior (bottom) in the mid-to-caudal region of the OE. Left column, In situ hybridization for $O R-Z 6$ (digoxigenin-labeled riboprobe) performed in an array of $15 \mu \mathrm{m}$ coronal cryosections of the OE from a wild-type mouse (129S3; postnatal day 24) is shown. $O R-Z 6^{+}$neurons are restricted to endoturbinate-II and -III and ectoturbinate-3 as indicated. Similar to lac $Z^{+}$neurons (right column ), OR- $Z 6^{+}$neurons are located at different depths of the OE; the most intensely labeled neurons are located in the apical OE. Right column, The overall distribution of $O R-Z 6$ mRNA is almost identical to the $\beta$-galactosidase expression pattern observed in an age-matched $\mathrm{H}$-lacZ6 mouse. As seen for OR-Z6 (boxed area, left column), X-gal-stained ORNs (right column) are concentrated on the tips of the central turbinates. To facilitate the comparison of the expression patterns for OR-Z6 mRNA and $\beta$-galactosidase, sections were chosen to match similar regions of the OE. Scale bar, $500 \mu \mathrm{m}$.
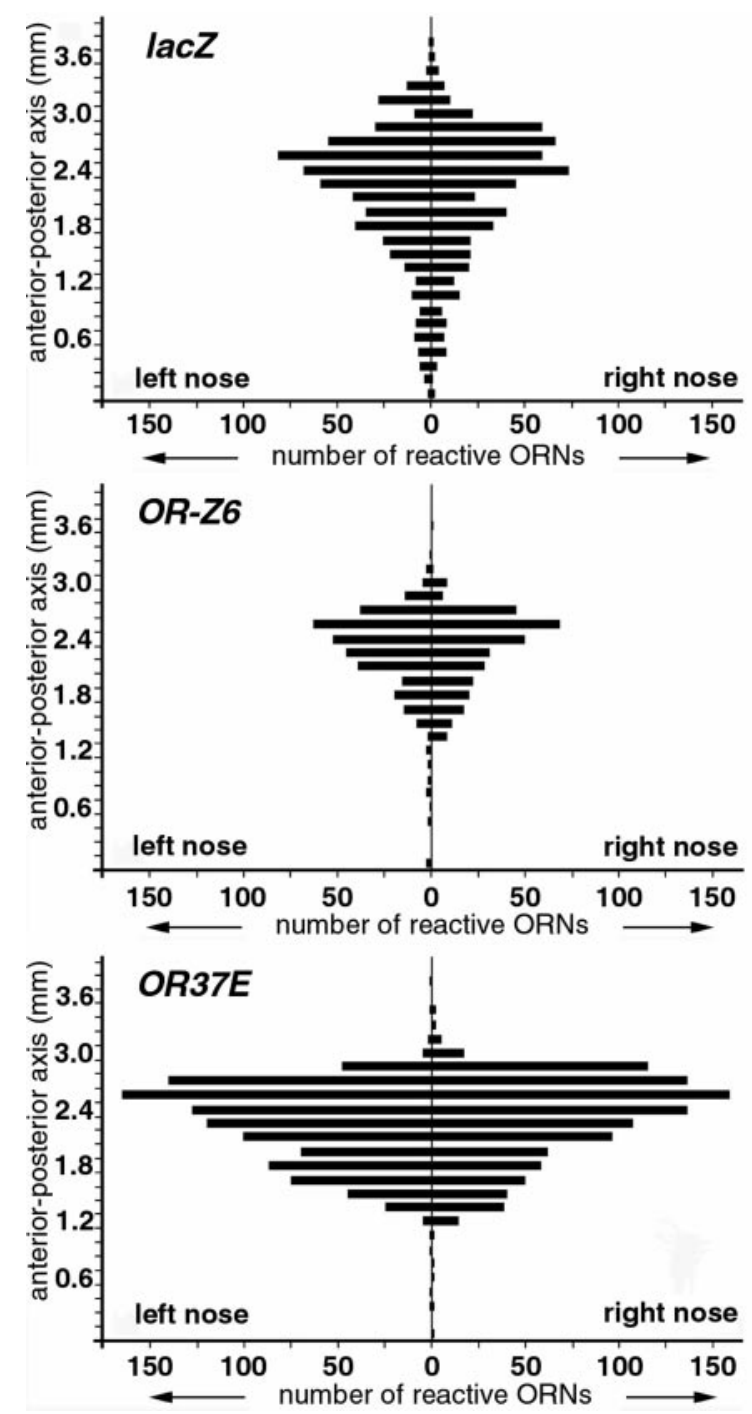

Figure 5. Anterior-to-posterior distribution of $\beta$-galactosidase (X-gal staining, top), OR-Z6 (in situ hybridization, middle), and OR37E (in situ hybridization, bottom) in separate but adjacent nose sections of the same P21 H-lacZ6 mouse. Starting at the organ of Masera $(0 \mathrm{~mm}), 15 \mu \mathrm{m}$ coronal cryosections were collected, and the labeled cells of every 10th section were counted and plotted along the anterior-to-posterior axis. The three expression profiles shown are nearly bilaterally symmetrical, and each of the three neuron phenotypes shows the highest density of reactive ORNs in the mid-to-caudal aspect of the $\mathrm{OE}$ at $\sim 2.6 \mathrm{~mm}$ posterior to the organ of Masera. ORNs expressing the lac $Z$ transgene were approximately twice as numerous as were $O R$ - $Z 6^{+}$neurons. Whereas a small number of $\beta$-gal ${ }^{+}$ORNs was evident in the region up to $1.2 \mathrm{~mm}$ posterior to the organ of Masera, almost no $O R-Z 6^{+}$or mOR37E ${ }^{+}$neurons were found in this anterior aspect. The unusually large number of mOR37E ${ }^{+}$ neurons is caused by cross-hybridization. The riboprobe used derives from the mOR37E coding region that is highly homologous among the four members of this subfamily, all of which are expressed in the same zone (Strotmann et al., 2000). The total numbers of labeled ORNs in the left or right nose of the $\mathrm{H}$-lacZ6 mouse analyzed were as follows: X-gal ${ }^{+}$, 5680 or 5780 ; OR-Z6 $6^{+}, 3400$ or 3240 ; and $\mathrm{mOR} 37 E^{+}, 10,230$ or 10,410 , respectively.

pattern, we included in situ hybridization for $O R 37 E$ on one set of sections (the OR37E subclone was kindly provided by J. Strotmann). The distribution of $\mathrm{OR}-\mathrm{Z6^{+ }}$ neurons in $\mathrm{H}$-lacZ6 mice was the same as that determined in wild-type mice, implying that the insertion of the reporter gene, close to the $O R-Z 6$ locus, apparently does not affect the $O R-Z 6$ expression pattern. Furthermore, 


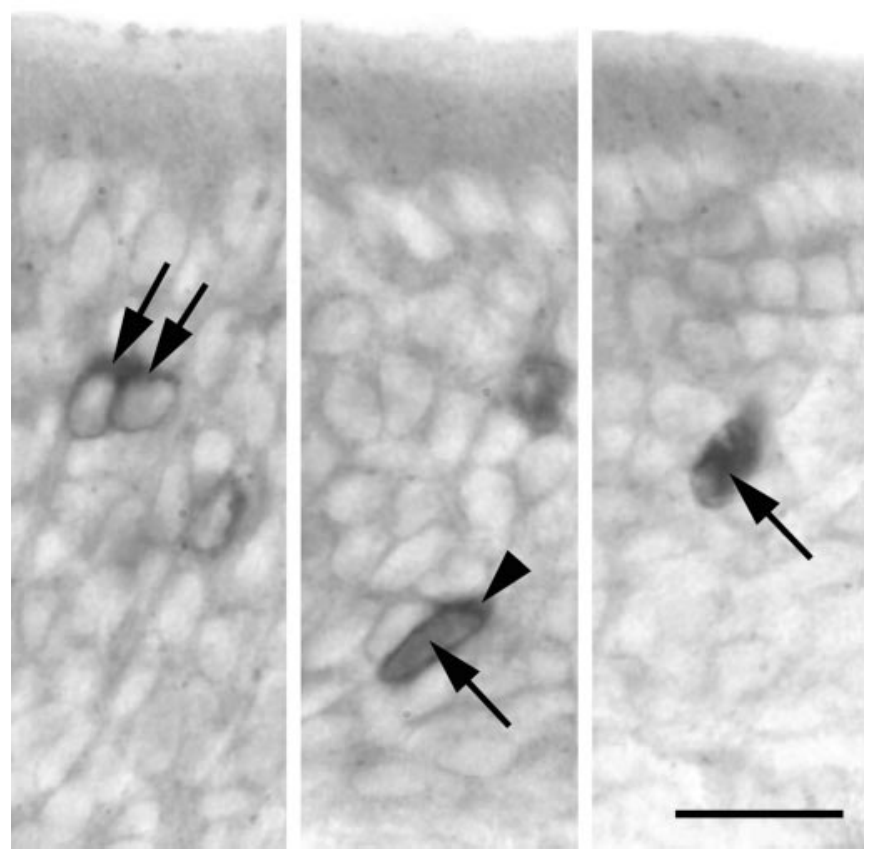

Figure 6. The three bright-field images illustrate the criteria by which olfactory neurons coexpressing the lac $Z$ transgene and $O R-Z 6$ were identified. $O R-Z 6$ in situ hybridization was performed using a digoxigeninlabeled $O R-Z 6$ riboprobe, and hybridization signals were detected and visualized using an alkaline phosphatase-conjugated anti-digoxigenin antibody and a substrate that developed a purple precipitate. Left, Hybridization signals were most prominent in the apical cytoplasmic portion and appeared triangular (arrows). In addition we observed a thin line surrounding the nucleus; the nucleus itself was usually white. Right, In contrast, ORNs that solely express the lac $Z$ transgene (arrow) were gray, including the cytoplasm covering the nucleus. Expression of $\beta$-galactosidase was detected using a primary anti- $\beta$-galactosidase antibody and visualized using a substrate yielding a gray precipitate. Middle, The double-labeled neuron shows a combination of both features described. The gray cytoplasm covering the nucleus indicates $\beta$-galactosidase expression (arrow), whereas the peak-shaped purple precipitate in the apical cytoplasm corresponds to OR-Z6 in situ hybridization (arrowhead). The three differently labeled neurons shown derive from the same coronal cryosection of a 35-d-old H-lacZ6 mouse and were closely associated on endoturbinate-II. Scale bar, $20 \mu \mathrm{m}$.

despite the different total numbers of labeled neurons per reaction, the highest numbers of ORNs labeled for $\beta$-galactosidase, OR-Z6, or mOR37E were found at $\sim 2.40-2.75 \mathrm{~mm}$ posterior to the organ of Masera (a small patch of OMP-positive ORNs separate from the main $\mathrm{OE}$ on both sides of the nasal septum) (Giannetti et al., 1995). This result confirmed and extended our previous findings that $O R-Z 6, \beta$-galactosidase, and $O R 37$ share a similar unusual spatial distribution pattern in the OE.

\section{Neuronal colocalization of $O R-Z 6$ and lacZ}

Because of the close chromosomal localization of $O R-Z 6$ and the $l a c Z$ transgene, together with their related expression patterns, we determined whether both genes are expressed in the same neurons. Double-labeling experiments in the OE of H-lacZ6 mice were performed by subjecting coronal cryosections to $O R-Z 6$ in situ hybridization before anti- $\beta$-galactosidase immunohistochemistry (IHC). In agreement with the result obtained from singlelabeling analyses, $\mathrm{OR}-\mathrm{Z} 6^{+}$and $\beta$-gal ${ }^{+}$neurons cosegregated at the tips of the central turbinates in all H-lacZ6 mice analyzed $(n=5)$. Surprisingly, only a small fraction of ORNs exhibited coexpression $\left(\mathrm{OR}-\mathrm{ZG}^{+}\right.$and $\beta$-gal ${ }^{+}$) (Fig. 6), whereas the majority of neurons was either $O R$-Z6-positive or $\beta$-galactosidase-positive. Among $2038 \beta$-gal ${ }^{+}$and $1070 \mathrm{OR}-Z 6^{+}$neurons counted in a P19 $\mathrm{H}$-lacZ6 mouse, 15 neurons showed double-labeling $(0.74 \%$ of the $\beta$-gal ${ }^{+}$population). Similar results were obtained from a P12 $\mathrm{H}$-lacZ6 mouse in which out of $1035 \beta$-gal ${ }^{+}$and $618 \mathrm{OR}-Z 6^{+}$ neurons, 6 ORNs showed double-labeling $\left(0.58 \%\right.$ of the $\beta$-gal ${ }^{+}$ population). The numbers presented derive from conservative counts, discarding any ambiguously double-labeled neurons. Furthermore, we noted that in situ hybridization before anti- $\beta$ galactosidase IHC decreases the number of immunolabeled neurons by $10-20 \%$. Thus, the actual number of double-labeled cells detected could be slightly higher. Reasoning that the population of $\mathrm{lac}^{+}$neurons in H-lacZ6 mice coexpresses other OR genes in addition to $O R-Z 6$, we performed double-labeling for $\beta$-galactosidase and $O R 37 E$ that exhibits a similar zonal restriction. Interestingly, among $6605 \mathrm{OR}_{37 E^{+}}$neurons and 2226 $\beta$-gal ${ }^{+}$neurons counted in a P35 H-lacZ6 mouse, 36 neurons exhibited coexpression (1.6\% of the $\beta$-gal ${ }^{+}$population). Despite the small number of H-lacZ6 mice investigated $(n=3)$, this analysis demonstrates that the expression of $\beta$-galactosidase does not exclude the coexpression of either $O R-Z 6$ or $O R 37 E$ in the same neuron.

\section{$O R-Z 6^{+}$ORNs project to a single glomerulus in each $\mathrm{OB}$}

The bulb projections of $O R-Z 6^{+}$neurons were assessed by in situ hybridization of serial coronal sections of the entire OBs using ${ }^{32} \mathrm{P}$-labeled antisense and sense riboprobes. To compare the position of hybridization signals among different mice, we defined the sections as percentages along the anterior-to-posterior axes of OBs. The first anterior section and the last posterior section containing glomeruli were set as 0 and $100 \%$, respectively. Analyses of four 2-week-old wild-type mice (129S3) and four 4-weekold $\mathrm{H}$-lacZ6 mice showed that axonal projections of $\mathrm{OR}-\mathrm{Z6} \mathrm{C}^{+}$ neurons preferentially converge onto a single glomerulus in each OB (Fig. 7). OR-Z6 ${ }^{+}$glomeruli were reproducibly located in the ventromedial portion of the anterior OBs, at approximately the rostral tip of the subventricular zone. Hybridization signals in the left and right bulbs of individual mice were nearly bilaterally symmetrical (Fig. 7). The positions of $O R-Z 6$-labeled glomeruli across all mice investigated varied between 19 and $26 \%$ of the bulb length, equaling a mouse-to-mouse variation of $250 \mu \mathrm{m}$ along the anterior-to-posterior axis (two to three glomerulus widths). Furthermore, in each one of the two mouse strains investigated, we detected an additional $O R-Z 6^{+}$glomerulus in one of the bulbs that was either directly adjacent to and in the same coronal plane as the primary one (129S3 line) or $300 \mu \mathrm{m}$ (three to four glomerulus widths) posterior to the primary one (H-lacZ6 line). The fact that these additional glomeruli were closely associated with the primary $O R-Z 6^{+}$glomerulus in the ventromedial $\mathrm{OB}$ is consistent with the general idea that OR gene expression plays a role in guiding axons to specific target sites in the OB (Mombaerts et al., 1996; Wang et al., 1998). In contrast to other reports (Mombaerts et al., 1996), we have never observed $\mathrm{OR}-\mathrm{ZG}^{+}$glomeruli in the lateral $\mathrm{OB}$ in any mice investigated.

\section{$O R-Z^{+}$glomeruli in $\mathrm{H}-l a c Z 6$ mice receive input from lac $Z^{+}$axons}

Previous reports showed that $\beta$-gal ${ }^{+}$ORNs in $\mathrm{H}$-lacZ6 mice project to many ventromedially located glomeruli of the anterior OBs (Treloar et al., 1996; Walters et al., 1996a; Cummings et al., 2000). These glomeruli exhibit different degrees of lac $Z$ expres- 


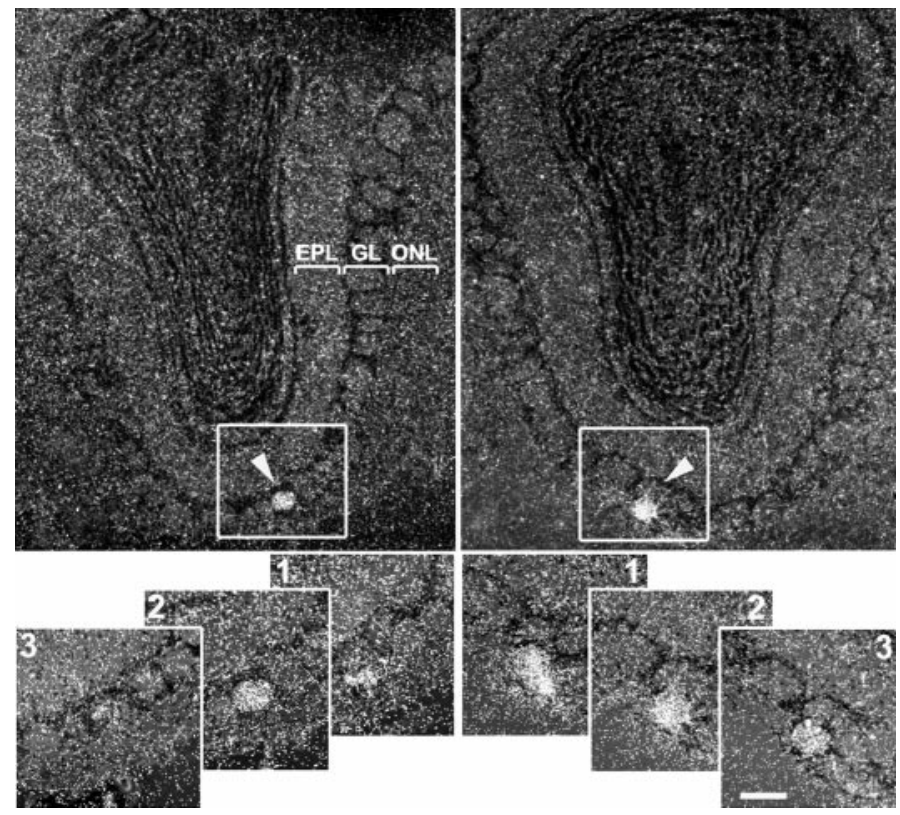

Figure 7. OR-Z6 neurons preferentially project to a single glomerulus in the main OB. In situ hybridization was performed on serial coronal cryosections of the entire OBs using a $\left[{ }^{32} \mathrm{P}\right] \mathrm{CTP}$-labeled antisense RNA probe of the OR-Z6 coding region. Subsequent counterstaining of periglomerular nuclei facilitated the identification of individual glomeruli in the glomerular layer $(G L)$. Top panels, The dark-field photomicrographs illustrate that axonal projections of $O R$-Z6-reactive neurons preferentially terminate onto a single ventromedial glomerulus in each $\mathrm{OB}$, as depicted by the arrowheads. Bottom panels 1-3, The hybridization signals (white grains) shown for this specimen were evident in three consecutive $18 \mu \mathrm{m}$ sections per bulb (boxed areas in top panels magnified). EPL, External plexiform layer; $O N L$, olfactory nerve layer. Scale bar: bottom panels 1-3, $50 \mu \mathrm{m}$.

sion because of the different number of $\mathrm{lac}^{+}$axons converging to each glomerulus. Of these, two to three glomeruli are heavily innervated by axons expressing the lac $Z$ transgene, but it remains to be shown whether all axons entering these glomeruli express lac Z. Because the positions we determined for $O R-Z 6^{+}$glomeruli (between 19 and $26 \%$ of the bulb length) coincide closely with those of the lac ${ }^{+}$glomeruli mapped recently in H-lacZ6 mice (Cummings et al., 2000), we next asked whether axons of both ORN phenotypes also project to the same glomeruli. Alternate coronal cryosections $(15 \mu \mathrm{m})$ of the entire OBs from young adult $\mathrm{H}-\mathrm{lacZ} 6$ mice were collected as two sets and separately subjected either to in situ hybridization using a ${ }^{32} \mathrm{P}$-labeled $O R-Z 6$ antisense riboprobe or to anti- $\beta$-galactosidase IHC. Analysis of two $\mathrm{H}$-lacZ6 mice showed that the single $O R-Z 6^{+}$glomerulus was always strongly labeled for $\beta$-galactosidase (Fig. 8), coinciding with one of the two to three heavily labeled $\mathrm{lac}^{+}$glomeruli. Consistently, the $O R-Z 6$ extra glomerulus detected in one of the H-lacZ6 bulbs (data not shown) exhibited lacZ labeling as well. The $\beta$-gal ${ }^{+}$fibers projecting to the $O R-Z 6^{+}$glomerulus most likely represent axonal projections of the double-labeled neurons detected in the OE. Thus, this analysis demonstrates that $O R$ $\mathrm{Z6}^{+}$glomeruli receive axonal input from at least two phenotypically distinct ORN populations $\left(O R-Z 6^{+}\right.$and $\beta-$ gal $^{+} ; O R-Z 6^{+}$ and $\beta$-gal ${ }^{-}$).

\section{DISCUSSION}

We demonstrate that locus-dependent mechanisms probably contribute to the zonal confinement of the $O M P-l a c Z$ reporter in
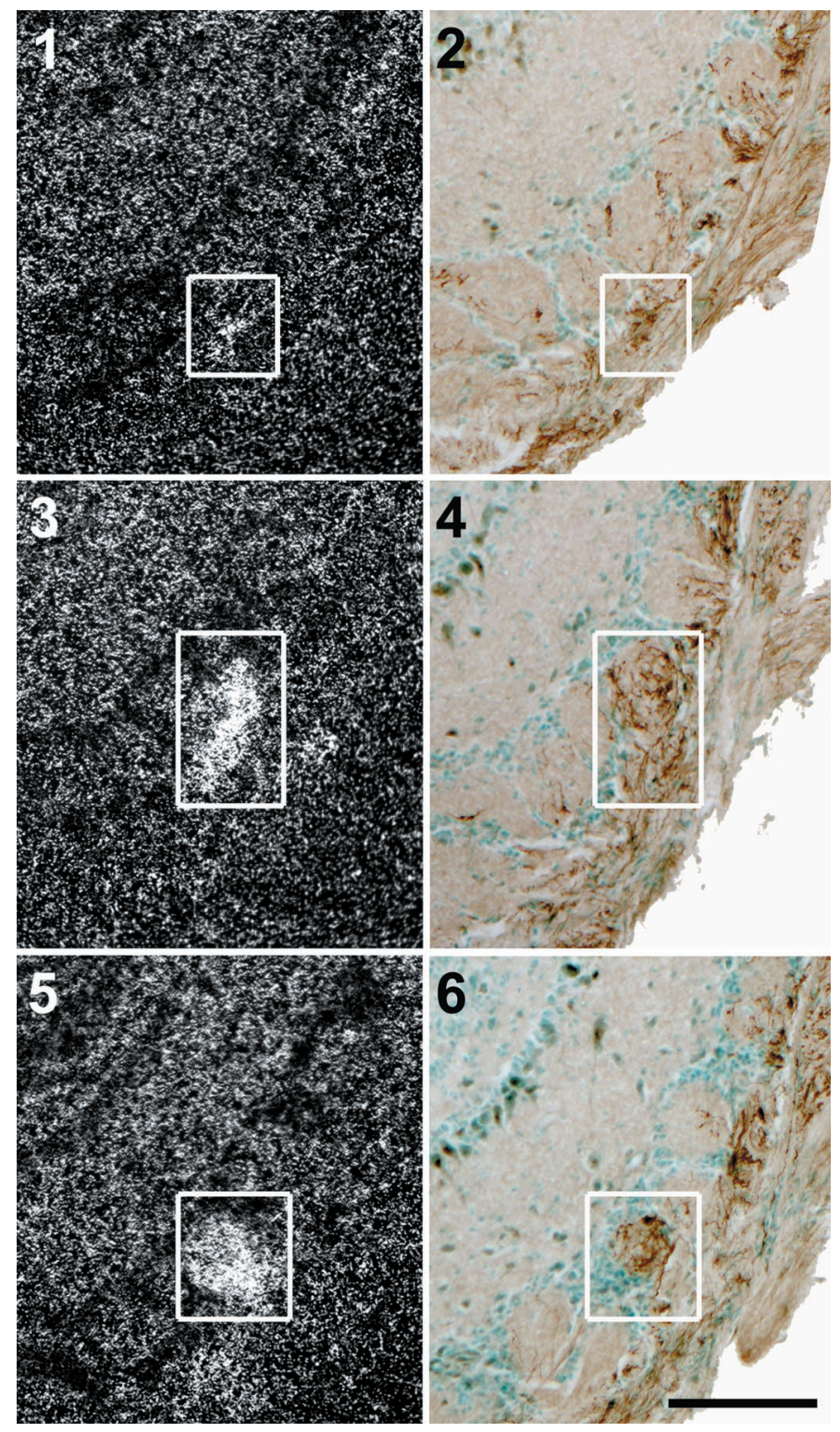

Figure 8. OR-Z6-positive glomeruli in $\mathrm{H}$-lacZ6 mice receive input from two phenotypically different ORN populations. IHC for $\beta$-galactosidase and in situ hybridization for OR-Z6 were performed on separate but adjacent sets of coronal cryosections $(15 \mu \mathrm{m})$ cut from the OB of a P26 $\mathrm{H}$-lacZ6 mouse. The panels show a series of higher magnifications of the ventromedial portion of the left OB. The order in which sections were taken along the anterior-to-posterior axis is indicated by the numbers 1-6. Hybridization signals for OR-Z6 appear as dense white grains (dark-field, left), whereas $\beta$-gal ${ }^{+}$axons are visible as brown fibers entering their target glomeruli (bright-field, right). Corresponding glomeruli in adjacent sections were aligned after identifying glomerular borders by counterstaining periglomerular nuclei. Comparison of labeled glomeruli in the two columns demonstrates that the $\mathrm{OR}-\mathrm{Z6}^{+}$glomerulus receives input from $\beta$-gal ${ }^{+}$axons as well (white boxed areas). The changing signal intensity for both $O R-Z 6$ and $\beta$-gal as the sections progress through the different depths of the glomerulus can be traced along the anterior-to-posterior axes of the three sections shown. Note the small number of $\beta$-gal ${ }^{+}$axons projecting to the $O R-Z 6$-labeled glomerulus. Scale bar, $100 \mu \mathrm{m}$.

H-lacZ6 mice (Walters et al., 1996a,b) that mimics the cellselective expression pattern known for some OR genes. Analysis of the transgene insertion site in $\mathrm{H}$-lacZ6 mice enabled us to identify and characterize the new OR gene $O R-Z 6$, the expres- 
sion pattern of which resembles that of the lac $Z$ reporter in $\mathrm{H}-\mathrm{lacZ6}$ mice.

$O R-Z 6$ is a typical OR gene the deduced protein sequence of which shares many features with the large multigene OR family. Sequence similarities to other ORs were as high as $66 \%$ but without selectivity to any known OR, indicating that $O R-Z 6$ defines a new subfamily. We mapped $O R-Z 6$ and the lacZ transgene to the proximal region of mouse chromosome 6 , close to Tcrb. Because this region shows synteny to human chromosome 7 , where $T c r b$ maps to $7 \mathrm{q} 35$, we predicted that human $O R-Z 6$ orthologs map to $7 \mathrm{q}$ as well. Analyzing a recent release of the human genome database, we identified three $O R-Z 6$ orthologs on human chromosome 7 that share $\sim 80 \%$ nucleotide sequence identity with mouse $O R-Z 6$. In contrast, mouse $O R-Z 6$ is likely a single OR gene in its subfamily, because we did not detect homologs by Southern blot analysis. The strong mouse-to-human homology suggests that $O R-Z 6$ is the first member of a distinct class of ORs that have been conserved during mammalian evolution. Interestingly, a recent hybridization study indicated that a mouse ortholog of the canine OR subfamily CfOLF3 (IsselTarver and Rine, 1997) resides proximal to the marker Tbxas1 on mouse chromosome 6 (Carver et al., 1998). No ORs were assigned to this region, and the canine receptor is only poorly homologous to $O R-Z 6$. Thus, OR-Z6 is the first cloned OR gene identified on mouse chromosome 6 .

\section{OR-Z6 expression is restricted to the medial OE}

Any given OR gene is expressed by an ORN subpopulation confined to one of four rostrocaudal zones of the mouse OE (for review, see Mombaerts, 1999). By contrast, our in situ data demonstrate that $O R-Z 6$ neuron distribution differs from this zonal rule. Although primarily confined to zone 2, OR-Z6 expression overlaps with neighboring zones and exhibits an unusual medial restriction by occupying the tips of the central turbinates only. Within this small subzone, $O R-Z 6$ neurons are randomly distributed, as implied by the coexistence of single-labeled neurons and small labeled ORN clusters. The overall pattern is bilaterally symmetrical between left and right nostrils and is present in both wild-type and H-lacZ6 mice. A similar distribution was reported for the mOR37 genes (Strotmann et al., 1999), the only other exception to the canonical OR expression patterns. In contrast to OR-Z6, mOR37 members share a six amino acid extension in the third extracellular domain (Strotmann et al., 1999; Hoppe et al., 2000) and map to mouse chromosome 4, near to two other OR genes that exhibit related expression patterns, but lack the loop extension. OR-Z6, on mouse chromosome 6 , has no significant sequence identity with the mOR37 genes, despite the related expression pattern. Our results demonstrate that the zonal confinement of OR expression is more complex than suggested by the arbitrary division into four rostrocaudal zones. We provide evidence of a medially restricted compartment having $O R-Z 6$ and the genes of the $m O R 37$ locus as the first members. This location exposes $O R-Z 6$ and $m O R 37$ to the main nasal airflow, implying a specific biological significance for these receptors. Thus, it would be of interest to explore the ligand chemistry of $O R-Z 6$ and mOR37.

\section{OR-Z6 ${ }^{+}$neurons project exclusively to the medial OB}

The unusual epithelial distribution is also reflected in OBs where axonal projections of $\mathrm{OR}-\mathrm{Z6}^{+}$neurons converge preferentially onto a single ventromedial glomerulus, as demonstrated by in situ hybridization. We occasionally identified secondary $\mathrm{OR}-\mathrm{Z6^{+ }}$ glo- meruli (see also Royal and Key, 1999; Gogos et al., 2000; Strotmann et al., 2000). Mapping analyses of the entire bulbs showed that $\mathrm{OR}-\mathrm{Z6}^{+}$glomeruli always reside ventromedial and within $19-26 \%$ of the rostrocaudal axis of the OBs. The close association of primary and secondary glomeruli reflects the topographic organization of the epithelium-to-bulb projections of $\mathrm{OR}-\mathrm{ZG}^{+}$ neurons, supporting the idea that OR proteins contribute to selecting specific target sites in the OBs (Mombaerts et al., 1996; Wang et al., 1998). Although their physiological significance is unknown, the presence or absence of extra glomeruli clearly demonstrates interindividual variation in olfactory coding. In contrast to reports indicating that axonal projections of ORNs expressing the same receptor each converge onto one lateral and one medial glomerulus per OB (Ressler et al., 1994; Vassar et al., 1994; Mombaerts et al., 1996), we have never observed lateral $O R-Z 6^{+}$glomeruli in the OBs of any mice. As for OR-Z6, ORNs expressing members of the mOR37 family (Strotmann et al., 2000) also project to single ventromedial glomeruli. In analogy to tracing studies investigating the patterns of epithelium-to-bulb projections (Astic and Saucier, 1986; Schoenfeld et al., 1994), we conclude that the ventromedial position for $\mathrm{OR}-\mathrm{Z6} 6^{+}$and $m O R 37^{+}$glomeruli is consistent with the medial restriction of the corresponding neurons in the OE.

\section{The OMP-lacZ-transgene mimics the OR-Z6 expression pattern}

The expression patterns of $O R-Z 6$ and the transgene in H-lacZ6 mice exhibit strong similarities, are confined to the tips of the central turbinates, and exist as separate, but overlapping, ORN populations. Whereas $O R-Z 6^{+}$neurons project primarily to a single glomerulus per $\mathrm{OB}, \mathrm{lac}^{+}$neurons, which are twice as numerous, converge to a variety of ventromedial glomeruli, exhibiting different degrees of lac $Z$ labeling. The overall distribution of $\mathrm{OR}-\mathrm{Z6}^{+}$neurons and their bulbar projections are indistinguishable in H-lacZ6 and wild-type mice, demonstrating that insertion of the $O M P-l a c Z$ construct close to the $O R-Z 6$ locus has little effect on the $O R-Z 6$ expression pattern. Despite their similar zonal confinement, the small number of double-labeled ORNs detected in $\mathrm{H}-\mathrm{lac} Z 6$ mice (1-2\%) shows that coexpression of lacZ and either $O R-Z 6$ or $m O R 37 E$ is independent and that transgene expression does not interfere with OR gene expression. $O R-Z 6^{+}$ glomeruli in the OBs of $\mathrm{H}-\mathrm{lacZ} 6$ mice are always positive for $\beta$-galactosidase. Because the number of $\mathrm{lacZ}^{+}$fibers in $\mathrm{OR}-\mathrm{Z6}^{+}$ glomeruli approximates the number of double-labeled ORN cell bodies in the OE, we conclude that these glomeruli receive input from two different $O R-Z 6^{+}$ORN phenotypes $\left(O R-Z 6^{+}\right.$and lac $Z^{-} ; O R-Z 6^{+}$and $\left.l a c Z^{+}\right)$, suggesting that singly lacZ-labeled neurons $\left(O R-Z 6^{-}\right.$and $\left.l a c Z^{+}\right)$that converge onto neighboring glomeruli express other ORs. This idea is consistent with reports demonstrating the importance of OR expression for precise axonal convergence (Mombaerts et al., 1996; Wang et al., 1998). $\mathrm{LacZ}^{+}$neurons in H-lacZ6 mice target a large number of glomeruli the overall topography of which is reestablished with remarkable accuracy after chemical deafferentation (Cummings et al., 2000). Thus, we propose that glomerular targeting of lac $Z^{+}$ neurons in H-lacZ6 mice relies on coexpression of OR genes, preferentially directed to the small medial subzone, of which $O R-Z 6$ and $m O R 37 E$ are the only two known examples. Furthermore, we speculate that the number of $\operatorname{lac}^{+}$glomeruli corresponds to the number of different OR genes expressed by the lac $Z^{+}$neuron population. The different levels of lac $Z$ labeling in 
H-lacZ6 glomeruli may reflect the different degrees to which $\mathrm{lac}^{+}$neurons coexpress other OR genes.

\section{Locus-dependent transgene expression in H-lacZ6 mice}

The similar spatial distribution of $l a c Z^{+}$and $O R-Z 6^{+}$neurons implies that the expression of both genes is linked. Because the transgene construct bears no OR gene identity, the question arises as to what molecular mechanisms lead to this pattern. The $\mathrm{H}-O M P-$ lac $Z$ construct consists of a truncated $O M P$ promoter containing the proximal olf-1 (O/E-1) binding site (Kudrycki et al., 1993; Wang and Reed, 1993), the lacZ coding region, and an SV40 polyadenylation sequence. Transgene expression in $\mathrm{H}-\mathrm{lacZ3}$ mice, another mouse line generated with this construct, showed that the truncated $O M P$ promoter serves as a minimal promoter, providing temporally and spatially correct expression in all mature ORNs (Walters et al., 1996a,b). In contrast, the expression pattern observed in H-lacZ6 mice implies the involvement of hierarchical mechanisms, capable of overriding the properties of the $O M P$ promoter in the lac $Z$ transgene and restricting lacZ expression not only to a specific zone but also to an ORN subpopulation within this zone, as opposed to the global ORN expression observed in $\mathrm{H}$-lacZ3 mice. Zonally active transcription factors, environmental cues, or lineage predetermination possibly contribute to this patterning. However, the $O R-Z 6$-like transgene expression in H-lacZ6 mice is likely caused by the site of transgene integration that occurred close to $O R-Z 6$. So-called position effects are well known in transgenic mice (Festenstein et al., 1996; Milot et al., 1996). This idea is consistent with studies showing that OR genes closely linked at specific loci exhibit similar expression patterns (Strotmann et al., 1999; Tsuboi et al., 1999; Serizawa et al., 2000). A transgenic approach demonstrated that the zonal affiliation of an OR promoter-driven reporter construct was dependent on the chromosomal insertion site (Qasba and Reed, 1998). Thus, we propose that the transgene pattern in H-lacZ6 mice is locus-predetermined and that the $O M P-l a c Z$ construct that randomly inserted near $O R-Z 6$ reports on its genomic environment. Similar locus-dependent mechanisms may apply to the mOR37 genes on mouse chromosome 4. In conclusion, our study strongly suggests that the expression of $O R-Z 6$ and the $O M P-l a c Z$ transgene is regulated via common, locus-dependent mechanisms that exemplify the locus-dependent regulation of OR gene expression.

\section{REFERENCES}

Asai H, Kasai H, Matsuda Y, Yamazaki N, Nagawa F, Sakano H, Tsuboi A (1996) Genomic structure and transcription of a murine odorant receptor gene: differential initiation of transcription in the olfactory and testicular cells. Biochem Biophys Res Commun 221:240-247.

Astic L, Saucier D (1986) Anatomical mapping of the neuroepithelial projection to the olfactory bulb in the rat. Brain Res Bull 16:445-454.

Ben-Arie N, Lancet D, Taylor C, Khen M, Walker N, Ledbetter DH, Carrozzo R, Patel K, Sheer D, Lehrach H, et al. (1994) Olfactory receptor gene cluster on human chromosome 17: possible duplication of an ancestral receptor repertoire. Hum Mol Genet 3:229-235.

Buck L, Axel R (1991) A novel multigene family may encode odorant receptors: a basis for odorant recognition. Cell 65:175-187.

Carver EA, Issel-Tarver L, Rine J, Olsen AS, Stubbs L (1998) Location of mouse and human genes corresponding to conserved canine olfactory receptor gene family. Mamm Genome 9:349-354.

Chess A, Simon I, Cedar H, Axel R (1994) Allelic inactivation regulates olfactory receptor gene expression. Cell 78:823-834.

Copeland NG, Jenkins NA (1991) Development and applications of a molecular genetic linkage map of the mouse genome. Trends Genet 7:113-118.

Cummings DM, Darren KE, Steven LS, Margolis FL (2000) Pattern of olfactory bulb innervation returns after recovery from reversible peripheral deafferentiation. J Comp Neurol 421:362-373.
Dulac C, Axel R (1995) A novel family of genes encoding putative pheromone receptors in mammals. Cell 83:195-206.

Ebrahimi FAW, Edmondson J, Rothstein R, Chess A (2000) YAC transgene-mediated olfactory receptor gene choice. Dev Dyn 217:225-231.

Emson PC, Shoham S, Feler C, Buss T, Price J, Wilson CJ (1990) The use of a retroviral vector to identify foetal striatal neurons transplanted into the adult striatum. Exp Brain Res 79:427-430.

Festenstein R, Tolaini M, Corbella P, Mamalaki C, Parrington J, Fox M, Miliou A, Jones M, Kioussis D (1996) Locus control region function and heterochromatin-induced position effect variegation. Science 271:1123-1125.

Giannetti N, Pellier V, Oestreicher AB, Astic L (1995) Immunocytochemical study of the differentiation process of the septal organ of Masera in developing rats. Brain Res Dev Brain Res 84:287-293.

Gogos JA, Osborne J, Nemes A, Mendelsohn M, Axel R (2000) Genetic ablation and restoration of the olfactory topographic map. Cell 103:609-620.

Graziadei PP, Graziadei GA (1979) Neurogenesis and neuron regeneration in the olfactory system of mammals. I. Morphological aspects of differentiation and structural organization of the olfactory sensory neurons. J Neurocytol 8:1-18.

Herrada G, Dulac C (1997) A novel family of putative pheromone receptors in mammals with a topographically organized and sexually dimorphic distribution. Cell 90:763-773.

Hoppe R, Weimer M, Beck A, Breer H, Strotmann J (2000) Sequence analyses of the olfactory gene cluster mOR37 on mouse chromosome 4. Genomics 68:284-295.

Issel-Tarver L, Rine J (1997) The evolution of mammalian olfactory receptors. Genetics 145:185-195.

Jenkins NA, Copeland NG, Taylor BA, Lee BK (1982) Organization, distribution, and stability of endogenous ecotropic murine leukemia virus DNA sequences in chromosomes of Mus musculus. J Virol 43:26-36.

Kudrycki K, Stein-Izsak C, Behn C, Grillo M, Akeson R, Margolis FL (1993) Olf-1-binding site: characterization of an olfactory neuronspecific promoter motif. Mol Cell Biol 13:3002-3014.

Lancet D, Ben-Arie N (1993) Olfactory receptors. Curr Biol 3:668-674.

Leinders-Zufall T, Lane AP, Puche AC, Ma W, Novotny MV, Shipley MT, Zufall F (2000) Ultrasensitive pheromone detection by mammalian vomeronasal neurons. Nature 405:792-796.

Li YS, Hoffman RM, Le Beau MM, Espinosa III R, Jenkins NA, Gilbert DJ, Copeland NG, Deuel TF (1992) Characterization of the human pleiotrophin gene. J Biol Chem 267:26011-26016.

Matsunami H, Buck L (1997) A multigene family encoding a diverse array of putative pheromone receptors in mammals. Cell 90:775-784.

Milot E, Strouboulis J, Trimborn T, Wijgerde M, de Boer E, Langeveld A, Tan-Un K, Vergeer W, Yannoutsos N, Grosveld F, Fraser P (1996) Heterochromatin effects on the frequency and duration of LCRmediated gene transcription. Cell 87:105-114.

Mombaerts P (1999) Molecular biology of odorant receptors in vertebrates. Annu Rev Neurosci 22:487-509.

Mombaerts P, Wang F, Dulac C, Chao SK, Nemes A, Mendelsohn M, Edmondson J, Axel R (1996) Visualizing an olfactory sensory map. Cell 87:675-686.

Ngai J, Dowling MM, Buck L, Axel R, Chess A (1993) The family of genes encoding odorant receptors in the channel catfish. Cell 72:657-666.

Osoegawa K, Tateno M, Woon PY, Frengen E, Mammoser AG, Catanese JJ, Hayashizaki Y, de Jong PJ (2000) Bacterial artificial chromosome libraries for mouse sequencing and functional analysis. Genome Res 10:116-128.

Qasba P, Reed RR (1998) Tissues and zonal specific expression of an olfactory receptor transgene. J Neurosci 18:227-236.

Ressler KJ, Sullivan SL, Buck LB (1993) A zonal organization of odorant receptor gene expression in the olfactory epithelium. Cell 73:597-609.

Ressler KJ, Sullivan SL, Buck LB (1994) Information coding in the olfactory system: evidence for a stereotyped and highly organized epitope map in the olfactory bulb. Cell 79:1245-1255.

Royal S, Key B (1999) Development of P2 olfactory glomeruli in P2internal ribosome entry site-tau-lac $Z$ transgenic mice. J Neurosci 19:9856-9864.

Ryba NJ, Tirindelli R (1997) A new multigene family of putative pheromone receptors. Neuron 19:371-379.

Schoenfeld TA, Clancy AN, Forbes WB, Macides F (1994) The spatial organization of the peripheral olfactory system of the hamster. Pt I, Receptor neuron projections to the main olfactory bulb. Brain Res Bull 34:183-210.

Serizawa S, Ishii T, Nakatani H, Tsuboi A, Nagawa F, Asano M, Sudo K, Sakagami J, Sakano H, Ijiri T, Matsuda Y, Suzuki M, Yamamori T, Iwakura Y, Sakano H (2000) Mutually exclusive expression of odorant receptor transgenes. Nat Neurosci 3:687-693.

Siracusa LD, Rosner MH, Vigano MA, Gilbert DJ, Staudt LM, Copeland NG, Jenkins NA (1991) Chromosomal location of the octamer tran- 
scription factors, $O t f-1, O t f-2$, and $O t f-3$, defines multiple $O t f$-3-related sequences dispersed in the mouse genome. Genomics 10:313-326.

Strotmann J, Wanner I, Krieger J, Raming K, Breer H (1992) Expression of odorant receptors in spatially restricted subsets of chemosensory neurons. NeuroReport 3:270-280.

Strotmann J, Wanner I, Helfrich T, Beck A, Meinken C, Kubick S, Breer H (1994a) Olfactory neurons expressing distinct odorant receptor subtypes are spatially segregated in the nasal neuroepithelium. Cell Tissue Res 276:429-438.

Strotmann J, Wanner I, Helfrich T, Breer H (1994b) Rostro-caudal patterning of receptor-expressing olfactory neurons in the rat nasal cavity. Cell Tissue Res 278:11-20.

Strotmann J, Hoppe R, Conzelmann S, Feinstein P, Mombaerts P, Breer H (1999) Small subfamily of olfactory receptor genes: structural features, expression pattern and genomic organization. Gene 236:281-291.

Strotmann J, Conzelmann S, Beck A, Feinstein P, Breer H, Mombaerts P (2000) Local permutations in the glomerular array of the mouse olfactory bulb. J Neurosci 20:6927-6938.

Sullivan SL, Adamson MC, Ressler KJ, Kozak CA, Buck LB (1996) The chromosomal distribution of mouse odorant receptor genes. Proc Natl Acad Sci USA 93:884-888.

Trask BJ, Friedman C, Martin-Gallardo A, Rowen L, Akinbami C, Blankenship J, Collins C, Giorgi D, Iadonato S, Johnson F, Kuo WL, Massa H, Morrish T, Naylor S, Nguyen OT, Rouquier S, Smith T, Wong DJ, Youngblom J, van den Engh G (1998) Members of the olfactory receptor gene family are contained in large blocks of DNA duplicated polymorphically near the ends of human chromosomes. Hum Mol Genet 7:13-26.
Treloar H, Walters E, Margolis F, Key B (1996) Olfactory glomeruli are innervated by more than one distinct subset of primary sensory olfactory neurons in mice. J Comp Neurol 367:550-562.

Tsuboi A, Yoshihara S, Yamazaki N, Kasai H, Asai-Tsuboi H, Komatsu M, Serizawa S, Ishii T, Matsuda Y, Nagawa F, Sakano H (1999) Olfactory neurons expressing closely linked and homologous odorant receptor genes tend to project their axons to neighboring glomeruli on the olfactory bulb. J Neurosci 19:8409-8418.

Vassar R, Ngai J, Axel R (1993) Spatial segregation of odorant receptor expression in the mammalian olfactory epithelium. Cell 74:309-318.

Vassar R, Chao SK, Sitcheran R, Nunez JM, Vosshall LB, Axel R (1994) Topographic organization of sensory projections to the olfactory bulb. Cell 79:981-991.

Walters E, Grillo M, Tarozzo G, Stein-Izsak C, Corbin J, Bocchiaro C, Margolis FL (1996a) Proximal regions of the olfactory marker protein gene promoter direct olfactory neuron-specific expression in transgenic mice. J Neurosci Res 43:146-160.

Walters E, Grillo M, Oestreicher B, Margolis FL (1996b) LacZ and $O M P$ are co-expressed during ontogeny and regeneration in olfactory receptor neurons of $O M P$ promoter-lac $Z$ transgenic mice. Int $\mathrm{J}$ Dev Neurosci 14:813-822.

Wang F, Nemes A, Mendelsohn M, Axel R (1998) Odorant receptors govern the formation of a precise topographic map. Cell 93:47-60.

Wang MM, Reed RR (1993) Molecular cloning of the olfactory neuronal transcription factor Olf-1 by genetic selection in yeast. Nature 364:121-126. 